The Intergenerational Causal Effect of Tax Evasion: Evidence from the Commuter Tax Allowance in Austria

by

Wolfgang FRIMMEL

Martin HALLA

Jörg PAETZOLD

Working Paper No. 1701

February 2017

Johannes Kepler University of Linz Department of Economics Altenberger Strasse 69 A-4040 Linz - Auhof, Austria www.econ.jku.at 


\title{
The Intergenerational Causal Effect of Tax Evasion: Evidence from the Commuter Tax Allowance in Austria ${ }^{\dagger}$
}

\author{
Wolfgang Frimmel ${ }^{\mathrm{a}, \mathrm{b}}$, Martin Halla ${ }^{\mathrm{b}, \mathrm{c}, \mathrm{d}}$, Jörg Paetzold ${ }^{\mathrm{e}}$

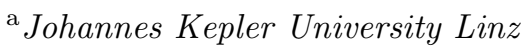 \\ ${ }^{\mathrm{b}}$ Christian Doppler Laboratory Aging, Health and the Labor Market \\ ${ }^{\mathrm{c}}$ University of Innsbruck \\ ${ }^{\mathrm{d}} I Z A$, Institute for the Study of Labor, Bonn \\ ${ }^{\mathrm{e}}$ University of Salzburg
}

February 14, 2017

(First version: January 19, 2017)

\begin{abstract}
Does tax evasion run in the family? To answer this question, we study the case of the commuter tax allowance in Austria. This allowance is designed as a step function of the distance between the residence and the workplace, creating sharp discontinuities at each bracket threshold. The distance to these brackets is a strong determinant of compliance since it corresponds to the probability of detection. The match of different administrative data sources allows us to observe actual compliance behavior at the individual level across two generations. To identify the intergenerational causal effect in tax evasion behavior, we use the paternal distance-to-bracket as an instrumental variable for paternal compliance. We find that paternal noncompliance increases children's non-compliance by about 20 percent.
\end{abstract}

JEL Classification: H26, A13, H24, J62, D14.

Keywords: Tax evasion, tax morale, intergenerational correlation, intergenerational causal effect.

\footnotetext{
${ }^{\dagger}$ Corresponding author: Jörg Paetzold, Department of Economics and Social Sciences and Salzburg Centre for European Union Studies (SCEUS), University of Salzburg, Residenzplatz 9, A-5010 Salzburg, Austria; email: joerg.paetzold@sbg.ac.at. For helpful discussions and comments we would like to thank Adrian Adermon, Anders Björklund, Christian Dustmann, Matthew J. Lindquist, Martin Plödt, Imran Rasul, Emmanuel Saez and seminar participants at Universities of Salzburg and Linz. The usual disclaimer applies. Financial support from the Austrian Science Fund FWF (project number J3719-G27) and from the Christian Doppler Laboratory 'Aging, Health and the Labor Market' is gratefully acknowledged.
} 


\section{Introduction}

The neo-classical model of tax evasion - an application of the economics of crime approach presented by (Becker, 1968) — predicts that citizens simply compare the expected benefits of evasion with the expected costs (Allingham and Sandmo, 1972; Yitzhaki, 1974). In essence, the tax evasion decision is similar to a portfolio decision, where citizens can choose between a risk-free asset (compliance, in this case) and a risky-asset (non-compliance). This model is straight-forward and provides intuitively appealing comparative static effects, where compliance increases in line with the probability of detection and the penalty. Unfortunately, such a model is unable to capture the full range of factors relevant to tax evasion in reality, as it consistently underpredicts real-world compliance (Alm et al., 1992). Many scholars presume that individuals are motivated not only by the rate of return on tax evasion, but also by other (e.g., social) motivations to pay taxes (usually called tax morale). While this appears to be a reasonable claim, it is notoriously hard to provide empirical evidence (Luttmer and Singhal, 2014).1

Whether tax morale drives compliance behavior is not only of interest to scholars, but also has strong implications for tax policy. If tax morale is indeed a quantitatively important determinant of compliance, policymakers could employ measurements beyond the usual deterrence policies. Ideally, we want to be able to assess which type of policy is more cost-effective to achieve a certain level of compliance. To do so, we need to identify the determinants of tax morale and, more specifically, understand how tax morale interacts with the extrinsic factors used in conventional deterrence policies.

In this study, we argue that the family seems to be the natural environment in which tax morale is shaped. We examine the intergenerational dimension and suggest interpreting the link between parents' and their children's behavir as "inherited tax morale". Therefore, we follow Luttmer and Singhal (2014) by understanding tax morale broadly as an umbrella term capturing non-pecuniary motivations for tax compliance $\left.\right|^{2}$ Our approach is also motivated by the key finding in the economic literature on crime that parental criminality is among the strongest predictors of the next generation's criminal activity (see, for e. g., Williams and Sickles, 2002; Hjalmarsson and Lindquist, 2012). This relationship holds for severe offences (such as violent crime), as well as for more minor offences and non-law abiding behavior such as drunk driving (Hjalmarsson and Lindquist, 2010). To our knowledge, no study has thus far examined such an intergenerational link in tax evasion behavior 3

\footnotetext{
${ }^{1}$ Complementary attempts to bridge the gap between theory and evidence focus on the role of the misperception of enforcement parameters (Chetty, 2009) and third-party reporting of income (Kleven et al., 2011, 2015).

${ }^{2}$ This comprises the intrinsic motivations to comply, peer effects, other social influences, information imperfections about deterrence parameters, and other factors that fall outside the standard expected utility framework.

${ }^{3}$ Notably, Halla (2012) shows that a survey-based measure of tax morale (not tax evasion) of second-
} 
In contrast to the above-mentioned studies of the intergenerational crime link, we not only provide an intergenerational association in tax compliance, but also aim to identify an intergenerational causal effect $\left.\right|^{4}$ Thus, we do not only want to answer the question of whether children are more likely to evade paying taxes if their parents were tax evaders; more importantly, we are interested in whether parental tax evasion causes children's non-compliance with the tax code. An association may simply reflect that parents and children share genetic and environmental factors that promote tax evasion. For instance, there is some evidence that certain genes are associated with deviant behavior (Veroude et al., 2016). If this holds for tax evasion behavior, we would observe a correlation between parents' and children's compliance behavior; however, it would be misleading to argue that parents' behavior is causing children's behavior. The distinction between these explanations for an observed correlation is important, since they require different policy responses. If tax evasion behavior across generations is causally linked, then policies that lower parental non-compliance will have spillover effects on the next generation. If, however, the intergenerational transmission only operates through genetic or environmental factors that are correlated with tax evasion, the same policy will be prone to fail.

The requirements for the identification of a causal effect are particularly high in the context of tax evasion. We tackle this problem by exploring a specific setting in which we can observe tax compliance behavior for two generations at the individual level. This is possible in the case of the commuter tax allowance in Austria, the largest standard deduction available for Austrian wage earners (Paetzold and Winner, 2016). This commuter allowance is designed as a step function of the distance between the residence and the workplace, creating sharp discontinuities at each bracket threshold. According to the Austrian tax code, employees report their eligibility for a certain distance bracket to the employer that, as the third party, has to validate these claims and adjust taxable income before withholding. In practice, however, employers do not sufficiently double-check these claims, turning the allowance into a (quasi-)self-reported item. Since the tax authorities have not systematically checked whether the self-reported information is accurate (until 2014), the scheme offered employees an easy opportunity to overreport their travel distance to work and hence receive a tax allowance higher than they were actually entitled to. Our linked administrative data sources allow us to observe not only the claimed allowance but also the true driving distance to work. This solves the key limitation of most tax evasion studies, which rarely observe the outcome of interest (Slemrod, 2007). We can thus observe the compliance behavior of all Austrian commuters at the individual

generation Americans is mainly and significantly influenced by the country of origin of their ancestors. This provides evidence that tax morale is inherited to some degree.

${ }^{4}$ Even in the literature on intergenerational mobility - the most heavily studied intergenerational link - only recently have empirical studies begun to focus on establishing a causal relationship between the education of parents and their children (Holmlund et al., 2011). These studies typically exploit changes in compulsory schooling laws. 
level, which allows us to distinguish between compliers and evaders quite accurately. We see a robust pattern in the data showing that the closer commuters live to a respective bracket threshold, the more prone they are to misreport their distance. In line with the neo-classical model, this can be interpreted as lower compliance for commuters with a lower probability of detection.

Information on family networks allows us to compare compliance behavior across generations. To establish an intergenerational causal effect in tax evasion, we use the father's distance-to-bracket (i.e., his probability of detection) to obtain exogenous variation in the father's compliance decision. Based on an instrumental variable (IV) approach we obtain a local average treatment effect that provides us with the effect of increased paternal tax evasion (because of a lower probability of detection) on the child's compliance. Thus, this estimate informs us about the spillover effects of a change in a conventional deterrence parameter for one generation on compliance by the next generation. We suggest interpreting the existence of such spillover effects as evidence in favor of tax morale. The identifying assumption is that the father's distance-to-bracket affects his child's compliance decision only through the channel of actual parental tax evasion behavior and is not correlated with any unobserved determinants of the child's tax evasion behavior. We demonstrate below that the distance-to-bracket is a highly idiosyncratic variable. For instance, we find no systematic relationship between any of the father's socioeconomic characteristics and his distance-to-bracket. We also find that the children of fathers with very different distances-to-bracket are observationally identical. Furthermore, we observe no evidence of individuals sorting or bunching around such bracket thresholds.

This study contributes to the established literature on tax evasion (Andreoni et al., 1998, Slemrod and Yitzhaki, 2002, Slemrod, 2007). Most recently, the empirical branch of this literature was enhanced by a number of valuable field experiments, which brought the credibility revolution to the study of tax compliance (Slemrod and Weber, 2012). However, most designs relying on experimental methods do not allow researchers to observe the development of tax compliance over longer periods. By contrast, our setting enables us to track the compliance behavior of all Austrian taxpayers who commute to work over time. This setting provides a rare opportunity to gain novel insights into how compliance behavior is transmitted through the most important social network, namely the family. To the best of our knowledge, our study is the first to examine the intergenerational link in tax evasion behavior 5 Based on palatable assumptions, we are able to identify an intergenerational causal effect: for our population, which has an average share of tax cheaters of about 20 percent, we find that a cheating father increases the likelihood of the

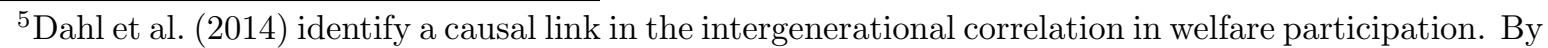
exploiting the random assignment of judges to Norwegian disability pension applicants as an instrument, they also establish a causal effect. This shows that when a parent is allowed a disability pension, their adult child's participation over the next five years increases by 6 percentage points. See also Bratberg et al. (2014). 
child's non-compliance by about 5 percentage points.

This finding also speaks to two further important, but difficult to study, aspects of the literature on tax compliance: spillovers and non-pecuniary motivations to comply. There exists some empirical evidence of enforcement spillovers on the compliance of non-audited taxpayers in one's network in the case of TV license fees (Rincke and Traxler, 2011; Drago et al., 2015) and of non-audited firms' suppliers along the VAT chain (Pomeranz, 2015). By contrast, evidence of complementary evasion spillovers regarding opportunities to cheat is extremely scarce. Paetzold and Winner (2016) show in the context of the Austrian commuter tax allowance that job changers moving to companies with a higher proportion of cheaters increase their cheating. Beyond that, we are only aware of related evidence from laboratory experiments, showing that taxpayers' reporting is sensitive to the evasion decision taken by other taxpayers (Fortin et al., 2007; Alm et al., 2009) ${ }^{6}$ The best empirical evidence of the importance of intrinsic motivation comes from two field experiments at the border between taxation and charitable giving, which use different treatments to analyze the determinants of compliance among members of the German Protestant and Catholic Church, respectively. Dwenger et al. (2016) show that starting from a zero deterrence situation, a sizeable proportion of existing intrinsic motivation to comply is driven by duty-to-comply preferences and that there is no crowding out between extrinsic and intrinsic motivations. By contrast, Boyer et al. (2015), who exploit a comparable set-up for the German Catholic Church, find a significant crowding out of intrinsic motivation among weakly intrinsically motivated taxpayers.

More broadly, our study also contributes to the large empirical literature studying the extent to which socioeconomic status is transmitted from parents to children (Bowles and Gintis, 2002). Traditionally, this literature has focused on educational attainment and earnings.7 More recently, it has also analyzed further dimensions and potential causal pathways - such as consumption (Charles et al., 2014; Bruze, 2015), health behavior (Thompson, 2014), and the willingness to compete (Almas et al. 2014) - to fully understand the intergenerational link. Tax evasion is a criminal activity that directly affects available income and potentially social status. As such it constitutes one of many causal pathways that underlie the intergenerational transmission of socioeconomic status.

The remainder of the paper is organized as follows: In Section 2, we present our research design. In Section 3, we present our estimation results of the intergenerational causal effect in tax evasion behavior, along with a placebo test, and a number of robustness checks. Section 4, examines the link between siblings and provides estimates of the intragenerational causal effect in tax evasion behaviour. Section 5 concludes the paper.

\footnotetext{
${ }^{6}$ Relatedly, Galbiati and Zanella (2012) present evidence of (aggregated) social externalities/multipliers in the context of evasion behavior, and Alstadsæter, Kopczuk and Telle (2014) highlight the importance of family networks in the adoption of a tax avoidance strategy.

${ }^{7}$ See, for instance, Björklund and Jäntti (1997); Aaronson and Mazumder (2008); Chetty et al. (2014)
} 


\section{Research design}

In this section, we first discuss the institutional background with a focus on the commuter allowance in the Austrian income tax system. Second, we present our data, describe how we compile our estimation sample, and provide descriptive statistics. Third, we explain our identification strategy and spell out under which assumptions we can identify an intergenerational causal effect in tax compliance.

\subsection{Institutional background}

\subsubsection{Commuter allowance in the Austrian income tax system}

In Austria, wage earners are not required to file a tax return since employers are legally obliged to do exact and cumulative withholding via the employees' payslip. On such a payslip, taxpayers can claim standard deductions and allowances, reducing their tax liability and hence the tax withholding. The commuter tax allowance is the largest of these standard allowances, enabling employees to reduce taxable income by as much as Euro 3,672 per year (for 2012). 8 Its intention is to compensate employees for their traffic expenses to work. The allowance comes as a step function of the commuting distance and offers higher rates if public transport is not available or unreasonably long. More precisely, the deductible amount increases with brackets of $2-20 \mathrm{~km}, 20-40 \mathrm{~km}, 40-60 \mathrm{~km}$ and more than $60 \mathrm{~km}$ of commuting (see Table 1). For each of these brackets (except for the first bracket of 2-20 km), there exists a scheme when public transport is in place, and another scheme if not. The tax code refers to these as the minor and major scheme. Eligible employees have to state the shortest commuting distance by means of public transportation (for the minor scheme) or by using a private vehicle (for the major scheme). Since the introduction of the commuter tax allowance in 1988, the distance brackets and basic structure of the allowance have remained unchanged.

To receive the commuter allowance via the payslip, employees report their eligibility for one of the four distance brackets as well as the availability of public transport to their employer, which, according to the tax code, should validate their claims before applying the respective commuter allowance to the tax withholding 9 In practice, however, it turns out to be a rather self-reported feature, with employers generally not meeting their responsibility to double-check the allowances claimed. To understand why non-compliance with the commuter allowance is possible, it is important to mention the main (mostly institutional) deficiencies regarding the enforcement of this tax allowance scheme. To begin

\footnotetext{
${ }^{8}$ Given a top tax rate of 50 percent (for incomes above Euro 60,000), the maximum amount of tax reduction is equal to Euro 1,836.

${ }^{9}$ Taxpayers can also claim the commuter allowance through the tax return at the end of the year. However, around 80 percent of commuter allowance recipients file for the allowance on their payslip (Statistik Austria, 2009). Furthermore, analyzing claims from payslips ensures that the compliance decision was taken by the taxpayer and not by a professional tax preparer.
} 
with, employers do not have large incentives to sufficiently validate the allowance claims since they do not carry/pay the deductible amount but simply adjust the withholding of their employees' income tax liability. Second, there has been a significant lack of deterrence for employers to thoroughly double-check the claims of their employees, keeping the risk of detection low. Only since 2014 have the tax authorities required claimants to use computer-assisted software to prove eligibility for a certain commuter allowance bracket. Third, since employees are not required to file a tax return at the end of the year, false reporting on the payslip can only be detected when the employer is audited. However, the tax authorities rarely focus on employees' deductions when conducting firm inspections. Finally, in the case of detection, the fine is typically levied on the employee but not on the third party, which is the employer. In sum, this lenient enforcement offered commuters an opportunity to overstate their travel distances and hence receive higher commuter allowances than actually entitled to.

\subsubsection{Detecting non-compliance with commuter tax allowances in adminis- trative tax data}

A procedure for uncovering tax evasion in the case of Austrian commuter tax allowances based on linked administrative data sources was first suggested by Paetzold and Winner (2016). We build on their approach and use an equivalent procedure to detect noncompliance with commuter tax allowances in our dataset. The starting point is the individual payslip files from the Austrian Ministry of Finance. These payslip files are similar to the W-2 forms in the United States and provide information on the wages and standard deductions of Austrian wage earners. From these forms, we extract information regarding the commuter allowance taxpayers received. For our analysis, we exclude claimants of the minor scheme (using public transport). This subset of claimants makes up around 30 percent of all commuter allowance recipients. The tax law requires commuters to state their eligibility based on the shortest travel distance to work. Since public transport usually makes detours when going from location $\mathrm{A}$ to $\mathrm{B}$, we are not in a position to measure the true commuting distance for recipients of the minor allowance precisely.

While the payslip files comprise information on the taxpayer's place of residence and the commuter allowance he/she received, they do not provide information on the location of the workplace. To obtain this information, we combine these data with information from the Austrian Social Security Database (henceforth ASSD). This administrative record is used to verify pension claims for the universe of Austrian workers in the private sector (Zweimüller et al., 2009). It is structured as a matched firm-worker dataset and includes detailed information on workers' employment and earnings histories. It also provides employer information, such as its location. Thus, the link between the two data sources enables us to observe both the residence and the workplace location of the tax- 
payer at the zip-code level $[10$ To identify unjustified (high) commuter allowances, we use a route planner to calculate the driving distances between the centroids of these two zipcodes (as is commonly used in navigation devices) and use this as an approximation of the true driving distance. Based on this true driving distance, we determine the justified commuter allowance bracket. A comparison between the justified allowance bracket and claimed allowance bracket reveals who evaded taxes. We classify individuals as overreporters (i.e., cheaters) when they received a higher allowance than they were entitled to, and as underreporters when they claimed too little of what they actually should have received.

Since we are especially interested in the compliance behavior of the second generation, we start by documenting the compliance behavior of cohorts born between 1974 and 1994 ${ }^{11}$ In total, 222,456 individuals from these cohorts received a major commuter tax allowance at least once during the period of our study. Table 2 summarizes the share of over- and underreporters of these cohorts, broken down by each allowance bracket. The table displays the misreporting of the first reporting decision (i.e., when individuals received the commuter tax allowance for the first time). The overreporting shares for the single brackets add up to 22 percent, 38 percent, and 31 percent, respectively. The underreporting shares vary by bracket between 5 and 12 percent.12 These skewed shares of under- and overreporting give a first indication that taxpayers cheat on their distance bracket in order to receive a higher allowance than they were entitled to. Since we also know the exact commuter allowances in Euros (see Table 1), we can also calculate the overclaimed amount of the commuter allowance by individuals. Hence, we can not only measure individual cheating behavior on the extensive margin, but also estimate tax evasion on the intensive margin.

To further uncover systematic cheating by commuters, we study discontinuities in misreporting around the allowance bracket thresholds. For this purpose, we pool data across all brackets and display the share of over- and underreporters by bins of distance to their employers. In the case that individuals systematically cheat on their bracket eligibility, we should observe a discontinuity in the proportion of over- and underreporters at the thresholds. By contrast, if people would just report a noisy estimate of their true bracket eligibility without any cheating, we should observe very similar shares of overand underreporting around the thresholds and no discontinuity.

\footnotetext{
${ }^{10}$ Notably, Austrian zip-code areas are fairly small. Their median surface area is $27 \mathrm{~km}^{2}$ and the median circumradius is about $3 \mathrm{~km}$. For comparison, the average surface area of a U.S. zip-code is around 300 $\mathrm{km}^{2}$. Important commuting areas have several zip-codes (e.g., Vienna alone is grouped into 23 zip-codes, hence commuters to those areas do not have the exact same commuting distance.

${ }^{11}$ For a documentation of the compliance behavior of older cohorts, see (Paetzold and Winner, 2016). In addition, we replicate Figure 1 for the father cohort (born before 1974) in the Web Appendix A.1.

${ }^{12}$ It is not uncommon to observe taxpayers reporting to their own disadvantage. Kleven et al. (2011) find significant overpayment of taxes (about 5 percent of self-reported income), and point at honest mistakes resulting from a complex tax code and misinformation as potential explanations for such behavior.
} 
The bars of Figure1 display the fraction of misreporters by commuting distance. Each bar is broken down into misreporters who overreport (dark area) and misreporters who underreport (light area). The dashed lines indicate the thresholds where the allowance discretely increases to a higher amount. We find a sharp reaction of taxpayers to these thresholds. The closer commuters live to a respective bracket the more prone they are to misreport their allowance claim. Overall, more than 60 percent (sum of over- and underreporters) of the individuals immediately below a bracket threshold misreport their actual driving distance to the workplace. Most importantly, we observe that the sharp discontinuity in the fraction of misreporters at the thresholds is mainly driven by overreporters. To be more precise, we find commuters to be much more prone to cheat than commuters underreporting their eligibility. For instance, in the bin immediately below the first 20 $\mathrm{km}$ threshold we find that 64 percent of all commuters overreport their allowance claim compared with only 29 percent of underreporters in the bin immediately above it. This discontinuity in misreporting at each threshold rejects explanations based on sole noise in our distance measure ${ }^{13}$ In fact, the discontinuity in misreporting exactly at the bracket thresholds strongly suggests that taxpayers take advantage of the self-reporting nature of the commuter allowance to overclaim their eligibility.

As shown in Figure 1, some underreporting occurs across the entire range of distance bins. The reason for this lies in the administrative nature of our data. Specifically, the ASSD provides no clear provision on whether the employer identifier is used for a firm or for single establishments of a (larger) firm. If only the headquarters of a company with several establishments across Austria is recorded in the ASSD, our estimate for the commuting distance between the firm's location and residence of its employees is upward biased for some workers. This inflates our share of underreporters, since we assign such workers a much greater distance (i.e., to the headquarters) than where they actually work (the local establishment). This is much less of an issue when measuring overreporting, since living close to a recorded headquarters in the ASSD, but commuting to a much more distant subsidiary is rare. This is also supported by the data, where we observe only a very small share of cheaters immediately above the bracket thresholds compared with a much higher share of underreporters immediately below the thresholds.

In sum, the pattern of misreporting we observe indicates that the compliance decision of commuters is affected by the threshold structure of the allowance scheme. Consistent with deliberate tax evasion, we observe misreporting to be much more widespread on the 'tax-favourable' side of each bracket threshold. Furthermore, the strong reaction of taxpayers to the bracket thresholds also indicates a decreasing (perceived) risk of detection

\footnotetext{
${ }^{13}$ For instance, false classification of commuters as misreporters caused by the use of zip-code centroids instead of actual addresses would predict symmetric increases and decreases in misreporting around the thresholds but no discontinuity. Furthermore, a very similar pattern of misreporting around the thresholds has been found by using one-year data containing exact addresses (including house numbers) from a large Austrian retailer (see Paetzold and Winner, 2016).
} 
when residing closer to such a bracket threshold. In the following, we use a taxpayer's distance-to-bracket as a proxy for his/her probability of detection.

While the pervasiveness of non-compliance with the commuter tax allowance might be striking, it is also interesting to note that a substantial number of individuals still report their commuting distance honestly. We use the richness of our data to address this variation in cheating, allowing for a compliance study over long periods of time to explore the transmission of non-compliance behavior over two generations.

\subsection{Linking tax reporting behavior across two generations}

The individual is the taxing unit in the Austrian income tax code and thus there is no joint filing of married couples or households. Starting from 1994, we have access to individual-level tax information, and examine children who are born between 1974 and 1994 (1,336,819 individuals). We focus on commuting children who claim the major commuter allowance $\left(222,456\right.$ individuals) ${ }^{14}$ We have to restrict our analysis to children born to married mothers (153,382 individuals), since administrative records do not include a link to fathers for children born out-of-wedlock. Furthermore, we focus on the intergenerational link between fathers and their children 15 Those father-child pairs are further required to be both active in the labor market and to have received the major commuter tax allowance at least once (34,319 individuals). The latter restriction causes the number of observations to drop substantially. The unit of observation is then a father-child pair in the year in which the child is applying for the major commuter tax allowance for the first time. To avoid any reversed causality, we only use those father-child pairs where the father received the commuter allowance in the past, namely before the child claimed the allowance for the first time (28,630 individuals). We further exclude father-child pairs that work in the same firm or have the same commute (i.e., possess an overlap in residential and firm postal codes; 24,675 individuals). This guarantees that fathers and children do not have the same probability of detection (multicollinearity problem). Furthermore, we restrict our analysis to observations where both father and child commute less than $60 \mathrm{~km}$. Taxpayers commuting more than $60 \mathrm{~km}$ are above the highest bracket threshold

\footnotetext{
${ }^{14}$ Please note that we find no any evidence of a correlation between children's probability of claiming the major commuter allowance and our IV for parental non-compliance (i.e., the father's distance-to-bracket). See our discussion below and in the Web Appendix A.2 for details.

${ }^{15}$ We are aware that an intergenerational transmission of tax evasion behavior may also work through mothers. However, labor force participation rates for mothers are much lower than those for fathers and may be rather selective. For instance, micro-census data reveal that the labor force participation rate of mothers with children younger than 15 was 66.3 compared with 92.1 percent of fathers in our last observation year of 2012. Furthermore, mothers had a part-time employment rate of 70.4 percent in 2012 (5.2 percent for fathers). However, the eligibility rules of the commuter tax allowance require (almost) full-time employment in practice. To avoid any potential problems of unobserved selection into labor supply, we therefore conduct our analysis only for fathers.
} 
and are thus not at risk of cheating $\sqrt{16}$ Finally, we end up with 15,522 unique father-child pairs.

\subsubsection{Descriptive statistics on the main variables}

Table 3 provides the average socioeconomic characteristics, tax evasion indicators, commuting distances and distances-to-bracket (probability of detection) for the studied fathers and children. To avoid potential problems of reverse causality i.e., children's cheating behavior affecting their fathers' behavior, we measure fathers' characteristics one year before children's characteristics (i.e., before the child claimed the commuter allowance for the first time).

Fathers are born between 1933 and 1981 and are on average 47 years of age when we measure their tax evasion behavior. Children are born between 1974 and 1994 and observed at about 24 years of age. The comparison of socioeconomic characteristics suggests that children experienced on average a social advancement. They are more often employed as white-collar workers, are less likely to have foreign citizenship (i.e., they have been partly naturalized), and are much more likely to hold an academic degree. Their log of annual income (measured on average at age 24) is 0.33 units lower than the log of fathers' annual income (measured on average at age 47), which corresponds to a difference of approximately Euros 9,500 per year ${ }^{17}$

The variables of primary interest are the tax evasion indicators regarding the commuter tax allowance. The binary indicators show that about 16 percent of fathers apply for a higher tax allowance than they are eligible. Among children the equivalent share is about 20 percent. Hence, children tend to cheat somewhat more often than their fathers. The other two tax evasion indicators reveal differences in the actual evaded amount. While fathers on average overclaim their commuter allowance by Euros 184, children do so by Euros 237. When relating the amount overclaimed to taxable income, we find that fathers on average evade 1.0 percent of their taxable income and children 1.6 percent.

Finally, Table 3 lists the average true commuting distance and average distance-tobracket. On average, fathers commute somewhat shorter distances compared with the average child (about 21 compared with $25 \mathrm{~km}$ ). By contrast, we find no difference in terms of the distance-to-bracket across generations. We see that the average father and average child have identical distances-to-bracket (9.5 km compared with $9.6 \mathrm{~km}$ ).

\footnotetext{
${ }^{16}$ The latter restriction turns out to be innocuous. Indeed, using the entire population of father-child pairs and assigning those with more than $60 \mathrm{~km}$ an extra indicator for their distance-to-bracket provides very comparable results (see Section 11 for details).

${ }^{17}$ However, wages in Austria increase with age and experience substantially. see also Frimmel et al. (2015).
} 


\subsection{Intergenerational correlations}

Table 4 summarizes several aspects of the intergenerational (father-child) and sibling correlations. In the former case, we distinguish all father-child pairs, father-son pairs, and father-daughter pairs. In the latter case, we consider all sibling pairs. For these pairs, we examine the associations among individual earnings, tax evasion, and commuting behavior. The first dimension is the most commonly used indicator in the well-established literature on intergenerational income persistence, the second dimension is the focus of our study, and the third dimension is related to our identification strategy. All variables are measured at the same point in time (i.e., when fathers are on average 47 years of age and children 24). The comparison of the intergenerational income persistence in our sample with (i) the respective benchmark estimates from this literature and (ii) with the intergenerational correlation in tax evasion allows us to put our novel results into perspective.

As expected, in our sample of matched fathers and children, we find clear evidence of intergenerational persistence in individual earnings. This persistence varies little with the sex of the child. We report the two most common measures of intergenerational income persistence, namely intergenerational elasticity and the rank-rank correlation. The intergenerational elasticity is the canonical measure and is obtained from a simple linear regression of children's logarithmic earnings on fathers' logarithmic earnings. Our slope coefficient of about 0.14 indicates that on average a high-earning father's child would have 14 percent more earnings than the child of a low-earning father. The rankrank correlation is an alternative measure based on a regression of children's rank in the income distribution on their father's respective rank ${ }^{18}$ We obtain a rank-rank correlation of about 0.18. As such, intergenerational income persistence in Austria is comparable to that in Canada, Germany, and the Nordic countries (Blanden, 2015, see Figure 1). The respective correlations between siblings are considerably smaller, but highly statistically significant throughout.

The intergenerational correlations in tax evasion are listed for our three tax evasion indicators (binary, overclaimed amount relative to income, overclaimed amount). In each case, we find a statistically significant positive correlation of about 0.05 to 0.06 . Thus, the intergenerational correlation in tax evasion behavior is roughly one-third of the intergenerational correlation in earnings. There is some evidence that the intergenerational correlations in tax evasion are somewhat higher for daughters compared with sons. In contrast to individual earnings, we observe for tax evasion that siblings and intergenerational correlations are comparable in magnitude. ${ }^{19}$

\footnotetext{
${ }^{18}$ We rank each father relative to the others based on his individual earnings. Similarly, we rank children relative to other children based on their individual earnings. We then compute the relationship between the child and parent ranks. The rank-rank correlation then identifies the correlation between children's and fathers' positions in the income distribution (Chetty et al., 2014).

${ }^{19}$ Eriksson et al. (2016), report for Sweden sibling correlations for different types of crimes, that are
} 
Regarding commuting behavior, we see a significant correlation in commuting distance of about 0.11 . Thus, children of fathers with a long commute tend to also have a higher commuting distance. Notably, we find no intergenerational correlation in terms of the distance-to-bracket. The latter result highlights the idiosyncratic nature of the distanceto-bracket, which forms the basis of our identification strategy.

\subsection{Estimation strategy}

To examine the intergenerational link in tax evasion behavior in a more systematic way, we relate in family $i$ the child's non-compliance, $N C_{i}^{c}$, to the father's past non-compliance, $N C_{i}^{f}$ :

$$
N C_{i, t=s}^{c}=\alpha+\tau \cdot N C_{i, t<s}^{f}+\beta \cdot \rho_{i, t=s}^{c}(d t b)+A \cdot X_{i, t=s}^{c}+B \cdot X_{i, t<s}^{f}+\epsilon_{i, t}^{c},
$$

where the superscripts $c$ and $f$ denote the child and father variables and coefficients. The child's compliance decision is measured when he/she claims the commuter tax allowance for the first time $(t=s)$. To rule out reverse causality, we measure the corresponding father's compliance behavior and all his characteristics in some period before the child claimed the commuter tax allowance for the first time $(t<s){ }^{20}$ The child's compliance behavior also depends on his/her specific probability of detection, $\rho_{i, t=s}^{c}(\cdot)$, and a variety of the observable child $\left(X_{i, t=s}^{c}\right)$ and father $\left(X_{i, t<s}^{f}\right)$ characteristics. The unobserved error term is captured by $\epsilon_{i, t}^{c}$.

The child's probability of detection is determined by his/her distance-to-bracket, where we include binary indicators capturing the following intervals: $[0-5) \mathrm{km},[5-10) \mathrm{km}$, and $>10 \mathrm{~km}$. The other control variables $\left(X^{c}, X^{f}\right)$ comprise the father's and child's true commuting distance (measured in $\mathrm{km}$ ). These enter linearly, squared, and with a binary indicator for short commuting distances $(<10 \mathrm{~km})$. Further, there are a variety of socioeconomic characteristics comprising sex, year of birth (binary indicators), citizenship (Austrian vs. non-Austrian), educational attainment (academic degree), occupation (blue- vs. white-collar worker), sector of employment (17 binary indicators), firm size (binary indicator for employment in a firm with more than 10 employees), individual earnings, and region of residence (9 binary indicators).

Sources of endogeneity An obvious problem in the estimation of Equation (1) is the potential endogeneity of $N C_{i, t<s}^{f}$. In particular, we are concerned that the father's tax evasion behavior is correlated with any unobserved determinant of children's compliance behavior included in $\epsilon_{i, t}^{c}$. Potential candidates for confounding factors can be either genetic

considerably higher. They do not provide correlations specific to tax evasion.

${ }^{20}$ When the father did not claim the commuter allowance in the year before the child started claiming, but rather claimed in an other year in the past, we take the closest year before the child's first time of claiming. This results in an average time difference between these two measurements of 3.5 years, with a median of 2 years. 
or environmental. Researchers have identified genes that are associated with criminal behavior (Veroude et al., 2016). If these genetic factors are also relevant for tax compliance, and if these are inherited from father to children, Equation (1) would suffer from endogeneity. Alternatively, father and child could share unobserved environmental factors such as a subjective evaluation of the deterrence parameters. These two sources of endogeneity would lead to an upward biased $\tau$. Thus, to obtain an unbiased $\tau$ that can be interpreted causally, we need exogenous variation in the father's compliance behavior.

\subsection{Instrumental variable strategy}

We suggest using the variation in the father's distance-to-bracket as an IV for his compliance. We associate a longer distance-to-bracket with a higher probability of detection and expect a higher compliance rate for these fathers. The identifying assumption of this IV strategy is that the father's distance-to-bracket is randomly assigned conditional on our covariates, and this affects the child's compliance behavior only through the channel of "inherited tax morale". While this assumption is fundamentally untestable, we provide a number falsification and plausibility checks confirming the idiosyncratic and exogenous nature of the bracket thresholds created by the tax law.

Firstly, we check whether we observe any sorting or bunching of commuters around the bracket thresholds. Therefore, we examine the distribution of the father's true commuting distance to work. We report a Kernel density plot to visually detect potential excess clustering around the bracket thresholds. Figure 2 displays the fathers' distance distribution, with the dashed lines representing the thresholds at which the allowance discontinuously jumps. We find no evidence of sorting or bunching of commuters around these bracket thresholds defined by the tax law. There is no observable spike or hump in the distance distribution around any of the three bracket thresholds. To further substantiate this finding, Figure 3 zooms in on each bracket threshold and provides McCrary tests to detect signs of discontinuity (McCrary, 2008). The estimate of the log change in height and its bootstrapped standard error are displayed directly on each graph and these confirm that we cannot detect a lack of continuity at any of the thresholds. We obtain an equivalent result when using bunching estimations in the spirit of Saez (2010); in other words, we find no evidence of excess clustering at any threshold (see Figure A.3 in the Web Appendix A.3.) All these findings strongly suggest that the bracket thresholds we used to construct our IV are exogenous to commuting distance. Put differently, there is no evidence that the bracket thresholds influence the location or commuting decisions of our population.

Secondly, we check whether there is any correlation between the father's and child's distance-to-bracket. We split the data into 20 equal-sized bins based on the distance-tobracket of the father and plot the mean distance-to-bracket of the child within each bin. 
The resulting binned scatter plot in Figure 4 shows that there is no relationship between the distance-to-bracket of the father (our IV) and that of the child. This finding indicates that there is no systematic sorting of children into home or firm location depending on their father's distance-to-bracket.

Thirdly, we perform balancing tests to check whether children's observable characteristics vary with their father's distance-to-bracket. Therefore, we distinguish between three groups with a low, medium, and high distance-to-bracket, which are defined by the following intervals: $[0-5) \mathrm{km},[5-10) \mathrm{km}$, and $>10 \mathrm{~km}$. Panel A of Table 5 compares the average child characteristics across these three groups defined by the father's distance-to-bracket. It turns out that the children, despite having fathers with different distances to the next threshold, are identical. Panel B of Table 5 compares the average father characteristics. Again, we observe that the groups are essentially identical.

Overall, we do not find a systematic relationship between individual characteristics and the distance-to-bracket, which forms the basis for our IV. In line with the graphical evidence presented above, our balancing tests confirm the premise that assignment to a distance-to-bracket is as good as random and not affected by any systematic sorting of individuals. Importantly, this also holds for the selection of children into claiming the major commuter allowance (see the Web Appendix A.2 for details).

Functional form of the first stage It is a priori unclear which functional form should be used to describe the relationship between the father's distance-to-bracket and his tax compliance. We explore several alternative specifications of the first-stage relationship in Table 6. The dependent variable is in each case a binary variable equal to one if the father evades taxes, and zero otherwise. In columns (1) to (4), we use semi-parametric specifications based on varying binary indicators for the different distance-to-bracket intervals. In column (5), we use a linear specification of the distance-to-bracket. Across all specifications we see that a higher distance-to-bracket significantly reduces the likelihood of cheating. For instance, the specification in column (1) shows that fathers with a distance-to-bracket between 5 and $20 \mathrm{~km}$ are about 30 percentage points less likely to cheat compared with fathers with a distance-to-bracket of $5 \mathrm{~km}$ or less. While the predictive power varies across the specifications, the F-statistics are all above 465. We replicate the analysis for the two alternative measurements of tax evasion. In Table 7, the dependent variable is the overclaimed amount relative to the father's income, while and the overclaimed amount in Euros is used in Table8. In both cases, we observe a significant negative effect of the distance-to-bracket on the extent of tax evasion, with sufficiently high F-statistics.

This set of estimations shows that the choice of the specific functional form of the first stage should not be decisive. As a baseline specification, we pick the semi-parametric specification from column (2) and provide the second-stage results for the other specifications in the sensitivity analysis section. 


\section{Estimation results}

\subsection{Intergenerational causal effect in tax evasion behavior}

Table 9 summarizes our main estimation results. For each of our three tax evasion indicators, we list the results from a simple OLS estimation and the second-stage estimates from a 2SLS estimation using the IV strategy described above. Both estimation methods provide evidence of a significant positive effect of the father's tax compliance behavior and child's compliance. Across all indicators, the 2SLS estimates are larger than the OLS estimates; however, the 95 percent confidence intervals overlap in each case. Our a priori belief about the source of endogeneity would imply a comparably smaller 2SLS estimate. The pattern of the larger 2SLS estimates is also common in the well-established literature on intergenerational income persistence (Havari and Savegnago, 2016) for two reasons: First, the 2SLS estimates correct both for classical measurement errors (which lead to a downward-biased OLS estimate) and for the endogeneity of the dependent variable. The former effect may dominate the latter one. Second, the 2SLS estimate is a local average treatment effect that refers to the specific sub-population whose behavior is affected by the IV being used (Imbens, 2010). By contrast, the OLS estimate provides an average effect treatment. The local average treatment effect may simply be larger than the (true) average treatment effect.

The 2SLS estimates suggest a substantial intergenerational causal effect in tax evasion behavior. The non-compliance of a father increases the likelihood of cheating for his child by 4.7 percentage points (see column (2)). Given an average non-compliance rate of 20 percent for children, the estimated effect amounts to a 24 percent increase in noncompliance among children. We interpret this result as evidence of an intergenerational transmission of tax morale, which is economically significant. The estimations using the other two indicators also provide information on the intensive margin: an increase in the overclaimed amount by the father of 1 percent of his income leads to an increase in the overclaimed amount by the child of 0.1 percent (see column (4)). In absolute terms, we observe that an increase by one Euro leads to an increase of 6 cents (see column (6)). The respective beta coefficients are comparable (0.056 compared with 0.051). All these estimates are significant at least at the 5 percent level and based on sufficiently strong IVs. The intergenerational causal effect is thus smaller along the intensive margin (compared with the extensive one). This results from the cap on the deductible amount defined by the commuter allowance (see Table 1).

When looking at the covariates included the model, we consistently find that only the child characteristics are decisive. Notably, all the estimated effects of the covariates (child and father characteristics) are almost identical in the 2SLS and OLS models. Thus, there seem to be no large correlations between the IVs and covariates. The most important determinant is the child's own distance-to-bracket. As expected, a shorter distance-to- 
bracket (reflecting a lower probability of detection) increases non-compliance considerably. The size of the estimated coefficients is comparable to those of the father in the respective first stage estimations. The effect of income on tax evasion is complex. We find that the probability of cheating and the overclaimed amount in Euros rises with income, while the overclaimed amount relative to income decreases with income. Remarkably, this finding is fully consistent with neo-classical model of income tax evasion. Allingham and Sandmo (1972) suggest that evasion increases with gross income, while the effect on the fraction of income evaded depends on relative risk aversion.21 Our finding implies that individuals exhibit a decreasing relative risk aversion. Moreover, we find that non-compliance is more wide-spread among white-collar workers. There are no significant differences in compliance behavior between men and women, Austrians and foreigners, and individuals with and without university degrees.

\subsection{Placebo test}

To test for any spurious correlations between our IVs and the outcome variable (i.e., the compliance behavior of the second generation), we further create placebo father-child pairs. In particular, we assign each father to a child in our dataset who is closest in terms of observable characteristics to his own child. We implement this via nearest neighbor matching, using the following list of observable characteristics: total commuting distance, distance-to-bracket, sex, year of birth, citizenship, educational attainment, occupation, earnings, firm size, sector of employment, and zip-code of residence. To increase the quality of our matches, we allow for replacement when applying the nearest neighbor match. Table 10 reproduces the estimations presented in Table 9 based on these placebo father-child pairs. Across all tax evasion indicators and methods, we find no significant effect of the matched father's tax compliance behavior on the child's compliance. Thus, the result of the placebo test suggest that the intergenerational transmission found in our main results is not driven by common trends towards non-compliance between the first and second generations in our data.

\subsection{Sensitivity analysis}

We conducted several additional analyses to verify the robustness of our findings. Table 11 summarizes the estimation results from selected alternative specifications of our estimation model. The estimates of the intergenerational causal effect in tax evasion turn out to be robust.

\footnotetext{
${ }^{21}$ In the Web Appendix A.4, we use survey data to replicate our estimation for the widely used selfreported tax morale. We observe that tax morale is higher among females, married individuals, older people, and those residing in more rural areas. It deteriorates with rising income, higher educational attainment and it is lower among self-employed individuals.
} 
Alternative first-stage specifications In the first two columns, we employ different functional form specifications of our first stage. In column (1), we use a semi-parametric specification based on four distance-to-bracket intervals (see column (3) of Table 6). The resulting second-stage estimates are identical to our baseline estimates. In column (2), we use a linear specification of distance-to-bracket intervals (see column (5) of Table 6). The resulting second-stage estimates are somewhat smaller, but still statistically significant. These tests corroborate that the identification of the causal effect is not driven by the specific functional form in the first stage.

Alternative estimation samples In the next two columns, we modify our estimation sample. In column (3), we also include fathers with a true commuting distance of more than $60 \mathrm{~km}$. We originally excluded these observations, since these fathers are not at risk of cheating owing to the construction of the commuter tax allowance. The inclusion of these additional observations changes our estimates only marginally. In column (4), we exclude all observations with fathers and/or children with comparably short commuting distances (less than $8 \mathrm{~km}$ ). The measurement error of the true commuting distance may be larger for this group. The estimated effect, however, hardly changes based on this reduced sample.

Controlling for the behavior of other peers In the remaining three columns, we control for the impact of other potential peer groups. Children's tax compliance behavior might also be influenced by their friends or co-workers. We approximate their circle of friends by referring to residents from the child's zip-code area born in the same year. We start by calculating the mean distance-to-bracket among this group, to which we refer below for simplicity as 'friends'. A potential concern might be that the father's distanceto-bracket is correlated with those of the child's friends. To test for this possibility, column (5) controls for the mean distance-to-bracket of the child's friends. Our estimates change only marginally. In column (6), we additionally control directly for the cheater share among the child's friends. While this additional control variable turns out to be statistically significant positive, our estimates of the intergenerational causal effect in tax evasion hardly change following the inclusion of this additional variable. Finally, in column (7), we control for the cheater share among the child's co-workers. In line with Paetzold and Winner (2016), we find a positive and strong relationship between the share of cheating co-workers and individual propensity to cheat. Again, the estimates of the intergenerational causal effect remain stable. 


\section{Evidence on siblings: intra-generational causal ef- fect in tax evasion behavior}

Is the causal link in tax evasion behavior unique to parents and their children, or do links exist in other networks as well? The siblings correlations presented in Section 2.3, and the final two sensitivity checks discussed in the previous section, which accounted for cheating among friends and co-workers, provide suggestive evidence for spillovers across other groups. In fact, the siblings and the intergenerational correlations are quite comparable in magnitude. In particular, the link between two brothers is quite strong (see Table 4). For friends and co-workers we also find substantial correlations. Based on the estimations presented in columns (6) and (7) of Panel A of Table 11, we find that an increase in the cheating share among the child's friends and co-workers by one standard deviation is associated with an increased likelihood of the child cheating of about 7 and 5 percentage points, respectively. Evidently, it is unclear to which degree these correlations capture a causal effect.

In this final section, we aim to identify the intra-generational causal effect in tax evasion behavior. We assume that the sibling who claimed the major commuter tax allowance first, may causally affect the compliance decision of the other sibling ${ }^{22}$ Our empirical specification using 9,650 pairs of siblings is equivalent to that summarized by eq. (1). Thus, we relate the tax compliance decision of the younger sibling to the past compliance of the older sibling. We use the distance-to-bracket of the older sibling as an IV for his/her tax evasion decision, and we assume that this variable affects the younger sibling's compliance behavior only through the older sibling's behavior. Under the validity of this assumption, the IV strategy solves the reflection problem of simultaneity.

Our findings summarized in Table 12 point to an intra-generational causal effect in tax evasion behaviour that is very comparable to the intergenerational causal effect. However, the estimated effects for siblings, have to be interpreted with some caution. Despite a very strong first stage, we obtain less precise second-stage estimates here.

\section{Conclusions}

Tax evasion is a widespread phenomenon that redistributes income from honest to dishonest citizens. The fight against tax evasion is a typical aspect of political agendas in

\footnotetext{
${ }^{22}$ We use the same sample selection criteria as for our main analysis (of father-child pairs), but focus now on all siblings, who claim the major commuter tax allowance, are born after 1973, are born to married mothers, and are active on the labor market. The unit of observation is a pair of first-claiming sibling - later-claiming sibling, in the year in which the later-claiming sibling is applying for the major commuter tax allowance for the first time. For the sake of simplicity, we refer below to the former as the 'older sibling', and to the latter as the 'younger sibling'. All covariates of the older sibling are measured before the younger sibling's year of observation.
} 
order to increase tax revenues and raise the efficiency of government. Tax evasion has also attracted the attention of scholars from various academic disciplines. There seems to be interdisciplinary agreement that individuals are motivated not only by the rate of return on tax evasion, but also by other motivations (usually called tax morale). Unfortunately, it is notoriously hard to test this supposition empirically. The key limitation is that tax evasion and tax morale are usually not observable to the researcher.

In this study, we resolve these key limitations. We focus on the case of the commuter tax allowance in Austria and combine various administrative data sources to observe actual tax evasion behavior at the individual level. We test the hypothesis that the family is important in shaping individual tax morale and is thus an important determinant of tax evasion. In a first step, we show the significant intergenerational association in tax compliance. In a second step, we utilize the exogenous variation in the father's tax evasion behavior to identify an intergenerational causal effect in tax evasion behavior. By exploiting the strong idiosyncratic variation in the father's probability of detection (our IV), we are able to show that paternal non-compliance increases children's non-compliance by about 20 percent. We also find evidence for spillovers across siblings.

These findings have two major implications. First, given that tax evasion behavior is causally linked across generations, policies that are able to reduce tax evasion today will have spillover effects on the next generation. Second, the specific nature of our IV allows us to conclude that a change in a conventional deterrence parameter (an "extrinsic factor") for one generation has positive effects on the tax morale (an "intrinsic factor") of the next generation. 


\section{References}

Aaronson, Daniel and Bhashkar Mazumder (2008), 'Intergenerational Economic Mobility in the United States, 1940 to 2000', Journal of Human Resources 43(1), 139-172.

Allingham, Michael G. and Agnar Sandmo (1972), 'Income Tax Evasion: A Theoretical Analysis', Journal of Public Economics. 1(3-4), 328-338.

Alm, James, Betty Jackson and Michael McKee (2009), 'Getting the Word Out: Enforcement Information Dissemination and Compliance Behavior', Journal of Public Economics 93(3-4), 392-402.

Alm, James, Gary H. McClelland and William D. Schulze (1992), 'Why Do People Pay Taxes?', Journal of Public Economics 48(1), 21-38.

Ålmas, Ingvild, Alexander W. Cappelen, Kjell G. Salvanes, Erik Ø. Sørensen and Bertil Tungodden (2014), Willingness to Compete: Family Matters, Discussion Paper Series in Economics 3, Department of Economics, Norwegian School of Economics.

Alstadsæter, Annette, Wojciech Kopczuk and Kjetil Telle (2014), Social Networks and Tax Avoidance: Evidence from a Well-Defined Norwegian Tax Shelter, Unpublished manuscript, Columbia University.

Andreoni, James, Brian Erard and Jonathan Feinstein (1998), 'Tax Compliance', Journal of Economic Literature 36(2), 818-860.

Becker, Gary S. (1968), 'Crime and Punishment: An Economic Approach', Journal of Political Economy 76(2), 169-217.

Björklund, Anders and Markus Jäntti (1997), 'Intergenerational Income Mobility in Sweden Compared to the United States', American Economic Review 87(5), 1009-1018.

Blanden, Jo (2015), 'Intergenerational Income Persistence', IZA World of Labor 176.

Bowles, Samuel and Herbert Gintis (2002), 'The Inheritance of Inequality', Journal of Economic Perspective 16(3), 3-30.

Boyer, Pierre C., Nadja Dwenger and Johannes Rincke (2015), Do Taxes Crowd Out Intrinisc Motivation? Field Experiment Evidence from Germany, Unpublished mansucript, University of Mannheim.

Bratberg, Espen, Øivind Anti Nilsen and Kjell Vaage (2014), 'Assessing the Intergenerational Correlation in Disability Pension Recipiency', Oxford Economic Papers 13, 1-22.

Bruze, Gustaf (2015), Intergenerational Mobility: New Evidence from Consumption Data, Unpublished mansucript, Karolinska Institute.

Charles, Kerwin Kofi, Sheldon Danziger, Geng Li and Robert Schoeni (2014), 'The Intergenerational Correlation of Consumption Expenditures', American Economic Review 104(5), 136-140.

Chetty, Raj (2009), 'Is the Taxable Income Elasticity Sufficient to Calculate Deadweight Loss? The Implications of Evasion and Avoidance', American Economic Journal: Economic Policy 1(2), 31-52. 
Chetty, Raj, Nathaniel Hendren, Patrick Kline and Emmanuel Saez (2014), 'Where is the Land of Opportunity? The Geography of Intergenerational Mobility in the United States', Quarterly Journal of Economics 129(4), 1553-1623.

Dahl, Gordon B., Andreas Ravndal Kostøol and Magne Mogstad (2014), 'Family Welfare Cultures', Quarterly Journal of Economics 129(4), 1711-1752.

Drago, Francesco, Frederike Mengel and Christian Traxler (2015), Compliance Behavior in Networks: Evidence from a Field Experiment, IZA Discussion Paper 9443, Institute for the Study of Labor, IZA, Bonn, Germany.

Dwenger, Nadja, Henrik Kleven, Imran Rasul and Johannes Rincke (2016), 'Extrinsic and Intrinsic Motivations for Tax Compliance: Evidence from a Field Experiment in Germany', American Economic Journal: Economic Policy 8(3).

Eriksson, Karin Hederos, Randi Hjalmarsson, Matthew J. Lindquist and Anna Sandberg (2016), 'The Importance of Family Background and Neighborhood Effects as Determinants of Crime', Journal of Population Economics 29(1), 219-262.

Fortin, Bernard, Guy Lacroix and Marie-Claire Villeval (2007), 'Tax Evasion and Social Interactions', Journal of Public Economics 91(1), 2089-2112.

Frimmel, Wolfgang, Thomas Horvath, Mario Schnalzenberger and Rudolf Winter-Ebmer (2015), Seniority Wages and the Role of Firms in Retirement, Unpublished manuscript, University of Linz.

Galbiati, Roberto and Giulio Zanella (2012), 'The Tax Evasion Social Multiplier: Evidence from Italy', Journal of Public Economics 96(5), 485-494.

Halla, Martin (2012), 'Tax Morale and Compliance Behavior: First Evidence on a Causal Link', The B.E. Journal of Economic Analysis \& Policy: Advances 12(1).

Havari, Enkelejda and Marco Savegnago (2016), Intergenerational Transmission of Education. A New Instrumental Variable Approach. Unpublished Manuscript.

Hjalmarsson, Randi and Matthew J. Lindquist (2010), 'Driving Under the Influence of Our Fathers', B.E. Journal of Economic Analysis 85 Policy: Topics 10(1), Article 100.

Hjalmarsson, Randi and Matthew J. Lindquist (2012), 'Like Godfather, Like Son: Exploring the Intergenerational Nature of Crime', Journal of Human Resources 47(2), 550582 .

Holmlund, Eelena, Mikael Lindahl and Erik Plug (2011), 'The Causal Effect of Parents' Schooling on Children's Schooling: A Comparison of Estimation Methods', Journal of Economic Literature 49(3), 615-651.

Imbens, Guido W. (2010), 'Better LATE than Nothing: Some Comments on Deaton (2009) and Heckman and Urzua (2009)', Journal of Economic Literature 48(2), 399423.

Kleven, Henrik Jacobsen, Claus Thustrup Kreiner and Emmanuel Saez (2015), Why Can Modern Governments Tax So Much? An Agency Model of Firms as Fiscal Intermediaries, NBER Working Paper 15218, National Bureau of Economic Research, Cambridge, MA. 
Kleven, Henrik Jacobsen, Martin B. Knudsen, Claus Kreiner, Søren Pedersen and Emmanuel Saez (2011), 'Unwilling or Unable to Cheat? Evidence From a Tax Audit Experiment in Denmark', Econometrica, 79(3), 651-692.

Luttmer, Erzo F. P. and Monica Singhal (2014), 'Tax Morale', Journal of Economic Perspectives 28(4), 149-168.

McCrary, Justin (2008), 'Manipulation of the Running Variable in the Regression Discontinuity Design: A Density Test', Journal of Econometrics 142(2), 698-714.

Paetzold, Jörg and Hannes Winner (2016), 'Taking the High Road? Compliance with Commuter Tax Allowances and the Role of Evasion Spillovers', Journal of Public Economics 143(1), 1-14.

Pomeranz, Diane (2015), 'No Taxation without Information: Deterrence and Selfenforcement in the Value Added Tax', American Economic Review 105(8), 2539-2569.

Rincke, Johannes and Christian Traxler (2011), 'Enforcement Spillovers', Review of Economics and Statistics 93(1), 1224-1234.

Saez, Emmanuel (2010), 'Do Taxpayers Bunch at Kink Points?', American Economic Journal: Economic Policy 2, 180-212.

Slemrod, Joel (2007), 'Cheating Ourselves: The Economics of Tax Evasion', Journal of Economic Perspectives 21(1), 25-48.

Slemrod, Joel and Caroline Weber (2012), 'Evidence of the Invisible: Toward a Credibility Revolution in the Empirical Analysis of Tax Evasion and the Informal Economy', International Tax and Public Finance 19(25-53).

Slemrod, Joel and Shlomo Yitzhaki (2002), Tax Avoidance, Evasion, and Administration, in A. J.Auerbach and M.Feldstein, eds, 'Handbook of Public Economics', Vol. 3, Elsevier, chapter 22, pp. 1423-1470.

Statistik Austria (2009), Statistik der Lohnsteuer 2008, Österreich verlag, Statistik Austria, Vienna, Austria.

Thompson, Owen (2014), 'Genetic Mechanisms in the Intergenerational Transmission of Health', Journal of Health Economics 35, 132-146.

Veroude, Kim, Yanli Zhang-James, Noelia Fernandez-Castillo, Mireille J. Bakker Bru Cormand and Stephen V. Faraone (2016), 'Genetics of Aggressive Behavior: An Overview', American Journal of Medical Genetics Part B: Neuropsychiatric Genetics 171(1), 3-43.

Williams, Jenny and Robin Sickles (2002), 'An Analysis of the Crime as Work Model: Evidence from the 1958 Philadelphia Birth Cohort Study', Journal of Human Resources 37(3), 479-509.

Yitzhaki, Sholomo (1974), 'A Note on Income Tax Evasion: A Theoretical Analysis', Journal of Public Economics 3(2), 201-202.

Zweimüller, Josef, Rudolf Winter-Ebmer, Rafael Lalive, Andreas Kuhn, Jean-Philippe Wuellrich, Oliver Ruf and Simon Büchi (2009), The Austrian Social Security Database (ASSD), Working Paper 0901, The Austrian Center for Labor Economics and the Analysis of the Welfare State, University of Linz. 


\section{Tables and figures (to be placed in the paper)}

Table 1: Commuter allowances in the Austrian tax code in Euro

\begin{tabular}{lcc}
\hline & \multicolumn{2}{c}{ Public transport } \\
$\begin{array}{l}\text { Distance } \\
\text { to bracket }\end{array}$ & $\begin{array}{c}\text { available } \\
\text { ('minot scheme') }\end{array}$ & \begin{tabular}{c} 
('major scheme') \\
\hline $2-20 \mathrm{~km}$
\end{tabular} \\
$20-40 \mathrm{~km}$ & - & 372 \\
$40-60 \mathrm{~km}$ & 1,356 & 1,476 \\
$>60 \mathrm{~km}$ & 2,016 & 2,568 \\
& & 3,672 \\
\hline
\end{tabular}

Table 2: Misreporting by distance-to-bracket intervals (cohorts born 1974-1994)

\begin{tabular}{lccc}
\hline & & \multicolumn{2}{c}{ Misreporters (in percent): } \\
\cline { 3 - 4 } $\begin{array}{l}\text { Distance } \\
\text { to bracket }\end{array}$ & $\begin{array}{c}\text { Number of } \\
\text { commuters }\end{array}$ & $\begin{array}{c}\text { Under- } \\
\text { reporters }\end{array}$ & $\begin{array}{c}\text { Over- } \\
\text { reporters } \\
\text { = cheaters }\end{array}$ \\
\hline $2-20 \mathrm{~km}$ & 83,538 & 12.4 & - \\
$20-40 \mathrm{~km}$ & 86,510 & 5.6 & 21.5 \\
$40-60 \mathrm{~km}$ & 29,877 & 7.3 & 38.2 \\
$>60 \mathrm{~km}$ & 22,531 & - & 31.3 \\
\hline All intervalls & 222,456 & 7.9 & 16.9 \\
\hline
\end{tabular}

Notes: This table summarizes misreporting of cohorts born between 1974-1994 (who have received the commuter allowance at least once) by distance-to-bracket intervals. Misreporting is measured when commuters receive the allowance for the first time (which was on average in the year 2006). Two types of misreporting are distinguished: underreporting and overreporting. The latter is equivalent to tax evasion. 
Figure 1: Share of misreporters by commuting distance

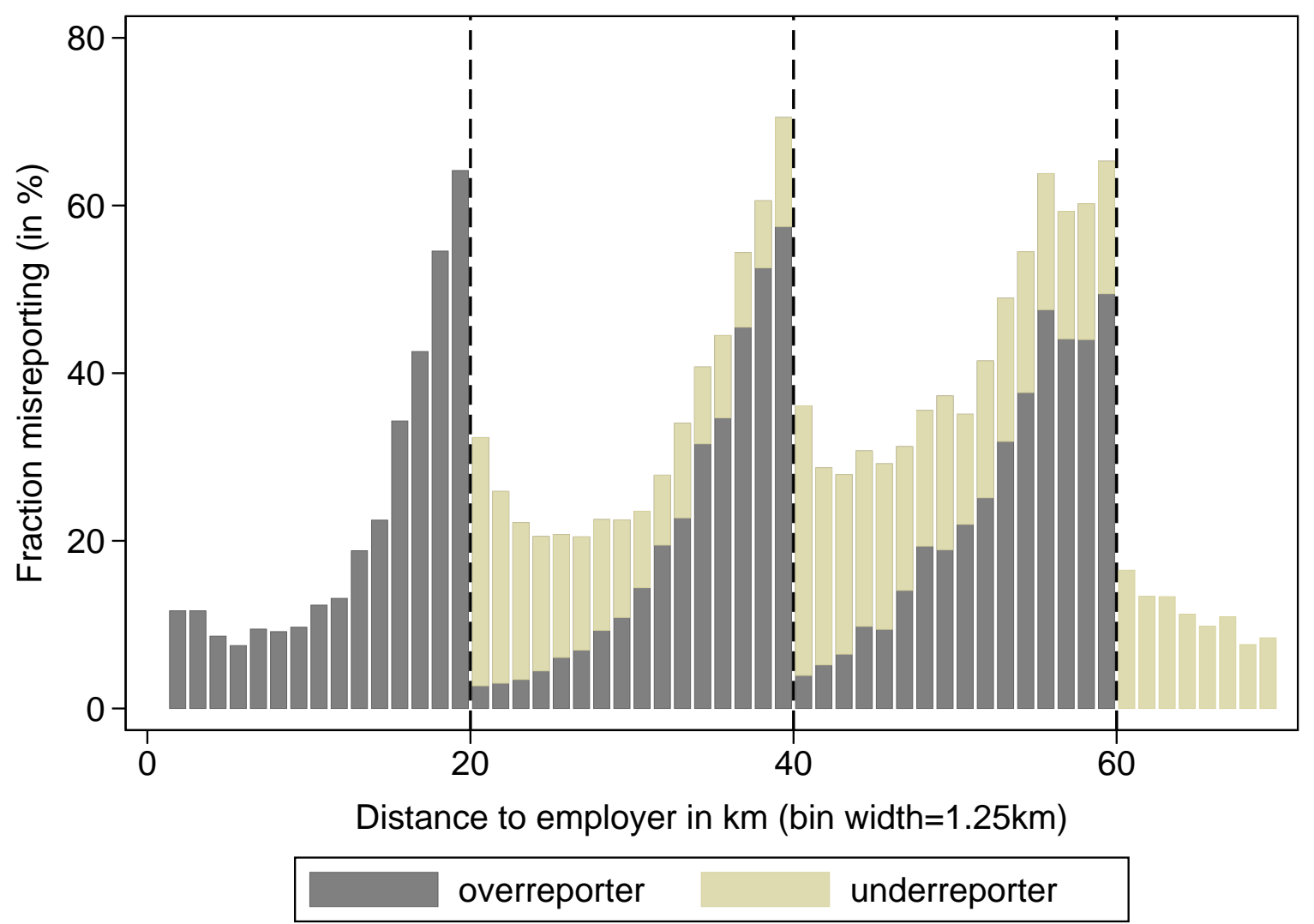

Notes: This figure displays the percent share of misreporters by commuting distance. Each bar is broken down between misreporters who overreport (dark area) and misreporters who underreport (light area). To give an example, the total fraction of misreporters in the $38.75-40 \mathrm{~km}$ bin is 69 percent, with 58 percent over- and 11 percent underreporter. The dashed lines represent the thresholds, where the allowance discontinuously increases to a higher amount (at 20, 40, and $60 \mathrm{~km}$, respectively). 
Table 3: Average characteristics of father and child

\begin{tabular}{lcc}
\hline & Father & Child \\
\hline Socioeconomic characteristics: & & \\
Age & 47.2 & 23.6 \\
& $(6.2)$ & $(3.8)$ \\
Female & & 0.44 \\
White collar worker & 0.31 & 0.48 \\
& $(0.47)$ & $(0.50)$ \\
Foreigner & 0.175 & 0.126 \\
Academic degree & 0.004 & 0.047 \\
Log of annual income & 10.39 & 10.06 \\
& $(0.394)$ & $(0.383)$ \\
Tax evasion indicators: & & \\
Cheater (1/0) & 0.159 & 0.199 \\
Overclaimed amount/income & 0.010 & 0.016 \\
& $(0.024)$ & $(0.041)$ \\
Overclaimed amount in Euro & 183.7 & 236.6 \\
& $(435.8)$ & $(495.2)$ \\
True commuting distance: & & \\
Distance in km & 21.4 & 24.7 \\
& $(13.3)$ & $(13.8)$ \\
Distance-to-bracket: & & \\
Distance-to-bracket in km & 9.54 & 9.57 \\
& $(5.27)$ & $(5.29)$ \\
\hline Number of observations & & 15,391 \\
\hline Notes: Standar deviations & & \\
& &
\end{tabular}

Notes: Standard deviations in parenthesis. 
Table 4: Intergenerational correlations in earnings, tax evasion, and in commuting behavior

\begin{tabular}{|c|c|c|c|c|c|c|}
\hline & \multicolumn{3}{|c|}{ Father - child correlations } & \multicolumn{3}{|c|}{ Sibling correlations ${ }^{a}$} \\
\hline & All & Sons & Daughters & All & Brothers & Sisters \\
\hline \multicolumn{7}{|l|}{ Individual earnings: } \\
\hline Intergenerational elasticity & $\begin{array}{c}0.137^{* * *} \\
(0.007)\end{array}$ & $\begin{array}{c}0.137^{* * *} \\
(0.010)\end{array}$ & $\begin{array}{c}0.145^{* * *} \\
(0.010)\end{array}$ & $\begin{array}{c}0.078^{* * *} \\
(0.009)\end{array}$ & $\begin{array}{c}0.076^{* * *} \\
(0.012)\end{array}$ & $\begin{array}{c}0.078^{* * *} \\
(0.013)\end{array}$ \\
\hline Rank-rank correlation & $\begin{array}{c}0.178^{* * *} \\
(0.008)\end{array}$ & $\begin{array}{c}0.182^{* * *} \\
(0.010)\end{array}$ & $\begin{array}{c}0.170^{* * *} \\
(0.012)\end{array}$ & $\begin{array}{c}0.146^{* * *} \\
(0.010)\end{array}$ & $\begin{array}{c}0.099^{* * *} \\
(0.014)\end{array}$ & $\begin{array}{c}0.118^{* * *} \\
(0.015)\end{array}$ \\
\hline \multicolumn{7}{|l|}{ Tax evasion indicators: ${ }^{b}$} \\
\hline Cheating & $\begin{array}{c}0.050^{* * *} \\
(0.009)\end{array}$ & $\begin{array}{c}0.045^{* * *} \\
(0.011)\end{array}$ & $\begin{array}{c}0.056^{* * *} \\
(0.014)\end{array}$ & $\begin{array}{c}0.052^{* * *} \\
(0.010)\end{array}$ & $\begin{array}{c}0.066^{* * *} \\
(0.013)\end{array}$ & $\begin{array}{l}0.034^{* *} \\
(0.015)\end{array}$ \\
\hline Overclaimed amount/income & $\begin{array}{c}0.060^{* * *} \\
(0.013)\end{array}$ & $\begin{array}{c}0.040^{* *} \\
(0.016)\end{array}$ & $\begin{array}{c}0.093^{* * *} \\
(0.023)\end{array}$ & $\begin{array}{c}0.041^{* * *} \\
(0.011)\end{array}$ & $\begin{array}{c}0.042^{* * *} \\
(0.013)\end{array}$ & $\begin{array}{c}0.039^{* *} \\
(0.018)\end{array}$ \\
\hline Overclaimed amount in Euro & $\begin{array}{c}0.052^{* * *} \\
(0.009)\end{array}$ & $\begin{array}{c}0.045^{* * *} \\
(0.012)\end{array}$ & $\begin{array}{c}0.062^{* * *} \\
(0.014)\end{array}$ & $\begin{array}{c}0.052^{* * *} \\
(0.010)\end{array}$ & $\begin{array}{c}0.068^{* * *} \\
(0.013)\end{array}$ & $\begin{array}{l}0.031^{* *} \\
(0.015)\end{array}$ \\
\hline
\end{tabular}

Commuting distance and distance-to-brackets: ${ }^{b}$

\begin{tabular}{|c|c|c|c|c|c|c|}
\hline Commuting distance (in $\mathrm{km}$ ) & $\begin{array}{c}0.111^{* * *} \\
(0.008)\end{array}$ & $\begin{array}{c}0.123^{* * *} \\
(0.011)\end{array}$ & $\begin{array}{c}0.097^{* * *} \\
(0.013)\end{array}$ & $\begin{array}{c}0.098^{* * *} \\
(0.010)\end{array}$ & $\begin{array}{c}0.114^{* * *} \\
(0.013)\end{array}$ & $\begin{array}{c}0.080^{* * *} \\
(0.015)\end{array}$ \\
\hline Distance-to-bracket (in km) & $\begin{array}{l}-0.003 \\
(0.008)\end{array}$ & $\begin{array}{c}0.003 \\
(0.011)\end{array}$ & $\begin{array}{l}-0.011 \\
(0.013)\end{array}$ & $\begin{array}{c}0.009 \\
(0.010)\end{array}$ & $\begin{array}{c}0.000 \\
(0.013)\end{array}$ & $\begin{array}{c}0.019 \\
(0.015)\end{array}$ \\
\hline Number of observations & 15,499 & 8,767 & 6,732 & 9,724 & 5,397 & 4,327 \\
\hline
\end{tabular}

Notes: Stars indicate statistical significance: ${ }^{*} p<0.10,{ }^{* *} p<0.05,{ }^{* * *} p<0.01$. ${ }^{a}$ The sibling correlations are computed between the oldest sibling and his/her younger siblings. Hence, the sample consists of all sibling pairs where both receive the major commuter allowance. The construction of the sibling sample follows exactly the sample selection criteria for our main estimation sample of father-child pairs (see section 2.2. ${ }^{b}$ Statistics shown in this category are simple pairwise correlations with standard deviations in brackets below. 
Figure 2: Distribution of father's true commuting distance

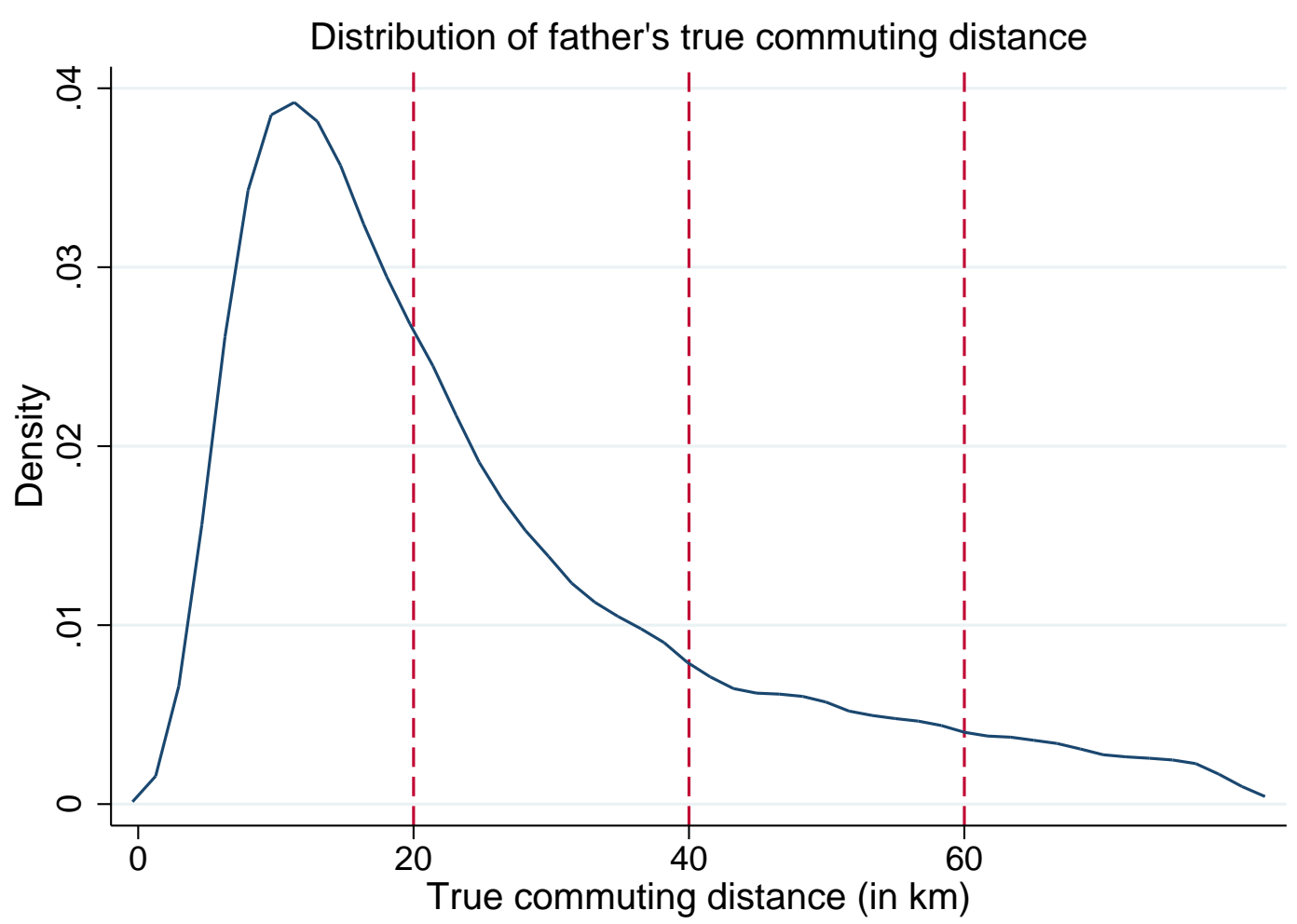

Notes: This figure plots the kernel density of the father's true commuting distance with a bandwidth of $1.25 \mathrm{~km}(N=15,391)$. The dashed lines represent the thresholds, where the allowance discontinuously increases to a higher amount (at 20, 40, and $60 \mathrm{~km}$, respectively). 
Figure 3: Distribution of father's true commuting distance around bracket thresholds

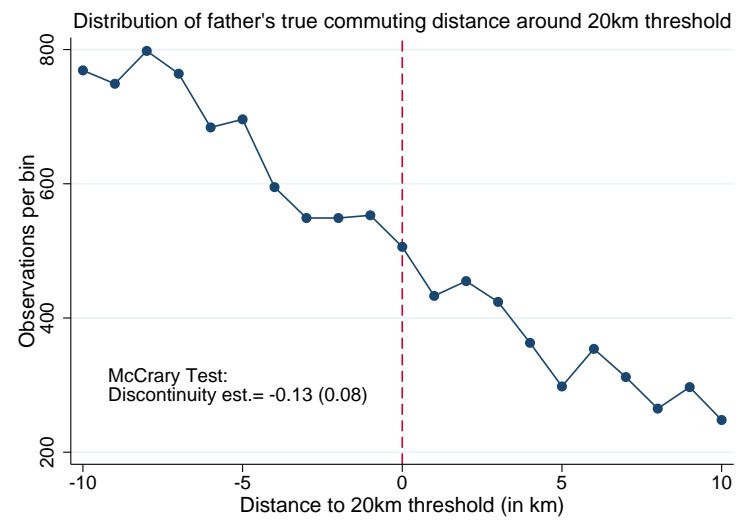

(a) Panel A

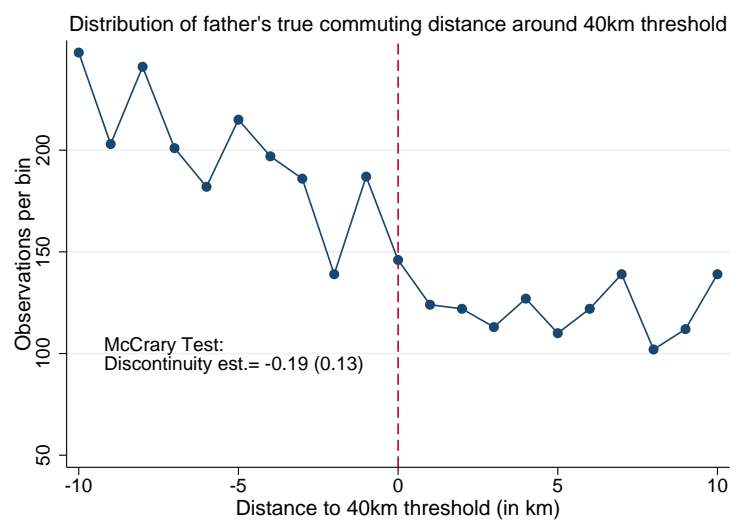

(b) Panel B

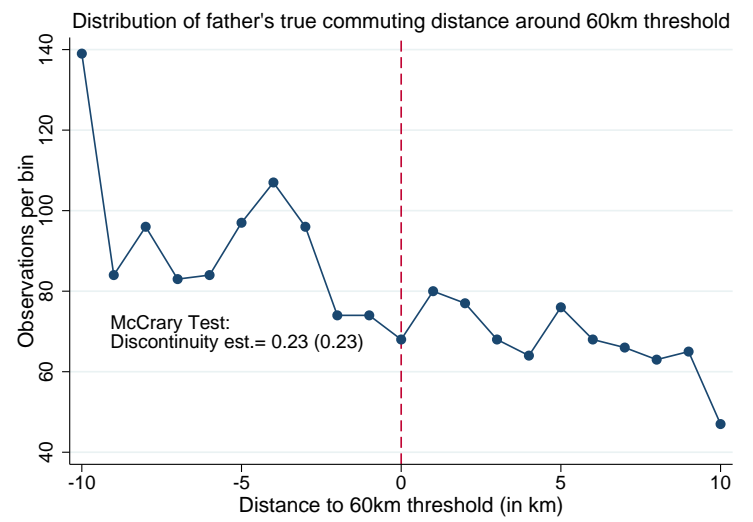

(c) Panel C

Notes: The figure assesses the smoothness of the distribution of fathers' true commuting distance around the bracket thresholds. In each panel, we put taxpayers in $1 \mathrm{~km}$ wide bins of distanceto-bracket and plot the number of individuals within these bins $(N=15,391)$. The dashed lines represent the bracket thresholds where the allowance discontinuously increases (i. e. zero represents the 20, 40, and $60 \mathrm{~km}$ threshold, respectively). Each graph also displays a McCrary test of the discontinuity of the probability density function at the respective bracket threshold. 
Figure 4: Distance-to-bracket of father vs. distance-to-bracket of child

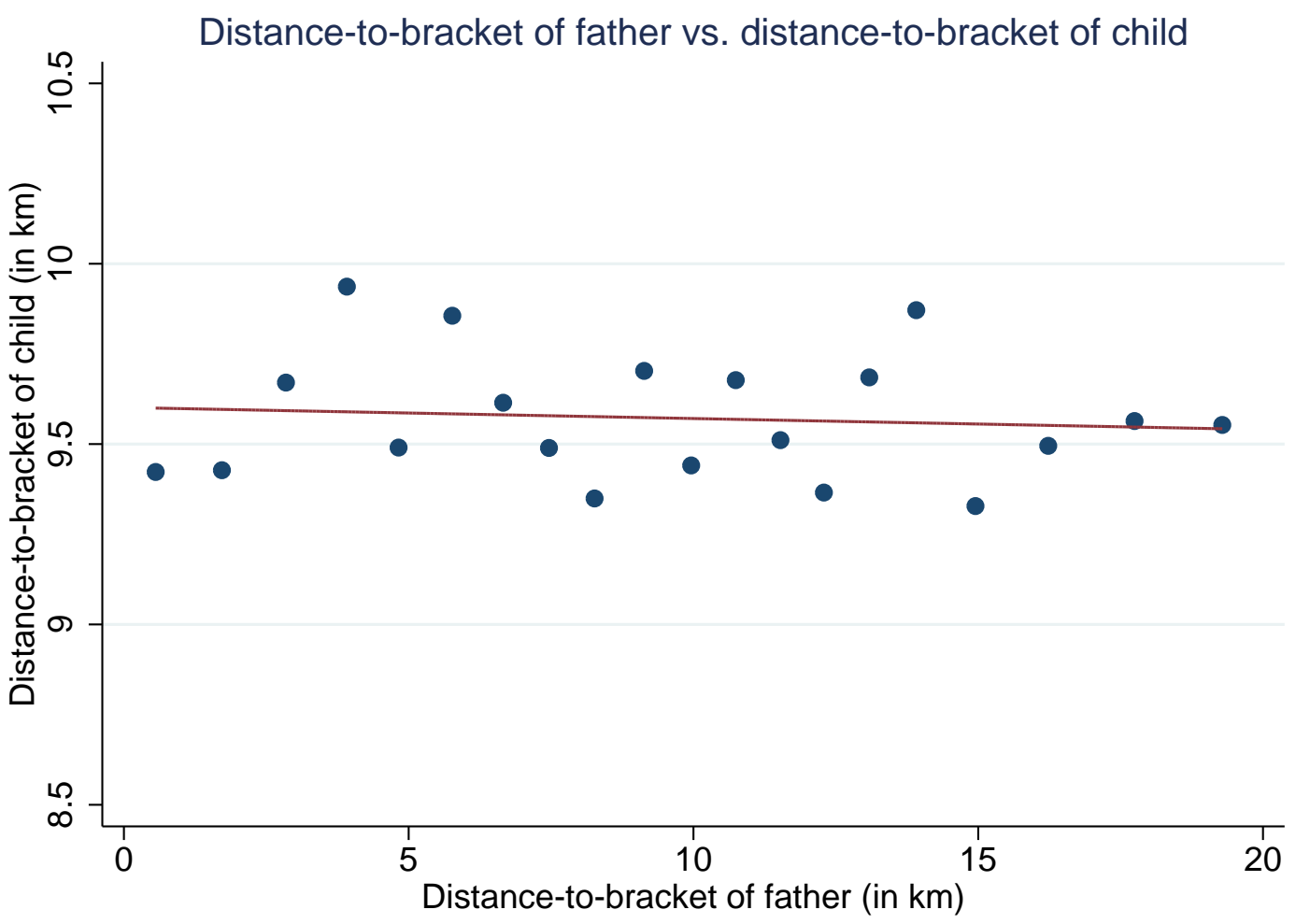

Notes: The figure displays the relationship between the distance-to-bracket of the father (our IV) and the distance-to-bracket of the child $(N=15,391)$. To construct the figure, we split the data into 20 equal-sized bins based on the distance-to-bracket of the father, and plot the mean distanceto-bracket of the child within each bin. The figure shows no systematic relationship between the distance-to-bracket of the father and the distance-to-bracket of the child. 
Table 5: Average child and father characteristics by father's distance-to-bracket

\begin{tabular}{|c|c|c|c|c|}
\hline & \multicolumn{4}{|c|}{ Father's distance-to-bracket } \\
\hline & $0-5 \mathrm{~km}$ & $5-10 \mathrm{~km}$ & $5-20 \mathrm{~km}$ & All \\
\hline \multicolumn{5}{|l|}{ Panel A: Child characteristics } \\
\hline Female & 0.43 & 0.45 & 0.43 & 0.44 \\
\hline Log of annual income & 10.07 & 10.06 & 10.06 & 10.06 \\
\hline Academic degree & 0.05 & 0.05 & 0.05 & 0.05 \\
\hline Age & 23.66 & 23.70 & 23.57 & 23.63 \\
\hline White collar worker & 0.48 & 0.49 & 0.48 & 0.48 \\
\hline Foreigner & 0.12 & 0.12 & 0.13 & 0.13 \\
\hline Employed in large firm ${ }^{a}$ & 0.41 & 0.42 & 0.41 & 0.41 \\
\hline Size of ZIP-code area & 40.85 & 41.01 & 40.22 & 40.60 \\
\hline Commuting distance (in $\mathrm{km}$ ) & 24.92 & 24.90 & 24.40 & 24.67 \\
\hline Distance-to-bracket (in km) & 9.59 & 9.60 & 9.55 & 9.57 \\
\hline \multicolumn{5}{|l|}{ Panel B: Father characteristics } \\
\hline Log of annual income & 10.42 & 10.39 & 10.39 & 10.40 \\
\hline Academic degree & 0.01 & 0.00 & 0.00 & 0.00 \\
\hline Age & 47.08 & 47.18 & 47.21 & 47.17 \\
\hline White collar worker & 0.33 & 0.30 & 0.31 & 0.31 \\
\hline Foreigner & 0.17 & 0.17 & 0.18 & 0.18 \\
\hline Employed in large firm ${ }^{a}$ & 0.49 & 0.47 & 0.47 & 0.47 \\
\hline Size of ZIP-code area & 40.86 & 41.54 & 37.96 & 39.70 \\
\hline Commuting distance (in $\mathrm{km}$ ) & 25.61 & 20.12 & 20.02 & 21.36 \\
\hline Number of observations & 3,650 & 4,569 & 7,303 & 15,522 \\
\hline
\end{tabular}

${ }^{a}$ Binary indicator for employment in a firm with more than 10 employees. 
Table 6: Alternative specifications of the first stage — binary cheating variable

(1)

(4)

2 IV categories 3 IV categories 4 IV categories 5 IV categories

Linear IV

Father's distance-to-bracket:

$0-2 \mathrm{~km}$

Base group

$0-5 \mathrm{~km}$

Base group

Base group

Base group

5-20 km

$-0.314^{* * *}$

$2-5 \mathrm{~km}$

(0.009)

5-10 km

N

$10-20 \mathrm{~km}$

$$
\begin{gathered}
-0.239^{* * *} \\
(0.011) \\
-0.397^{* * *} \\
(0.010)
\end{gathered}
$$

$10-15 \mathrm{~km}$

$15-20 \mathrm{~km}$

linear in $\mathrm{km}$

Father and child covariates ${ }^{a}$

Number of observations

Mean of dep. variable

F-test of weak instrument

Shea's R-squared

0.13

$\begin{array}{cr}\text { Yes } & \text { Yes } \\ 15,391 & 15,39 \\ 0.16 & 0.16 \\ 1093.76 & 753.07 \\ 0.13 & 0.15\end{array}$

0.15

$\begin{array}{cc} & -0.229^{* * *} \\ & (0.018) \\ -0.240^{* * *} & -0.388^{* * *} \\ (0.011) & (0.016) \\ & \\ & \\ -0.383^{* * *} & -0.521^{* * *} \\ (0.012) & (0.016) \\ -0.406^{* * *} & -0.547^{* * *} \\ (0.010) & (0.015)\end{array}$

Notes: Standard errors clustered on families in parentheses, stars indicate statistical significance:* $p<0.10,{ }^{* *} p<0.05,{ }^{* * *}$ $p<0.01{ }^{a}$ We control for the following characteristics of father and child: year of birth (binary indicators), citizenship (Austrian vs. non-Austrian), educational attainment (academic degree), occupation (blue- vs. white-collar worker), sector of employment (17 binary indicators), firm size (binary indicator for employment in a firm with more than 10 employees), individual earnings, region of residence (9 binary indicators), commuting distance in $\mathrm{km}$ (linearly, squared, and with a binary indicator for short commuting distances $<10 \mathrm{~km}$ ), size of ZIP-code area of residence (linear and squared). Further we control for the child's sex and distance-to-bracket, where we include binary indicators capturing the following intervals: $[0-5) \mathrm{km},[5-10) \mathrm{km}$, and $>10 \mathrm{~km}$. 
Table 7: Alternative specifications of the first stage — overclaimed amount/income

\begin{tabular}{|c|c|c|c|c|c|}
\hline & $(1)$ & $(2)$ & $(3)$ & $(4)$ & $(5)$ \\
\hline & 2 IV categories & 3 IV categories & 4 IV categories & 5 IV categories & Linear IV \\
\hline \multicolumn{6}{|c|}{ Father's distance-to-bracket between: } \\
\hline $0-2 \mathrm{~km}$ & & & & Base group & \\
\hline $0-5 \mathrm{~km}$ & Base group & Base group & Base group & & \\
\hline $5-20 \mathrm{~km}$ & $\begin{array}{c}-0.018^{* * *} \\
(0.001)\end{array}$ & & & & \\
\hline $2-5 \mathrm{~km}$ & & & & $\begin{array}{c}-0.013^{* * *} \\
(0.001)\end{array}$ & \\
\hline $5-10 \mathrm{~km}$ & & $\begin{array}{c}-0.013^{* * *} \\
(0.001)\end{array}$ & $\begin{array}{c}-0.014^{* * *} \\
(0.001)\end{array}$ & $\begin{array}{c}-0.022^{* * *} \\
(0.001)\end{array}$ & \\
\hline $10-20 \mathrm{~km}$ & & $\begin{array}{c}-0.023^{* * *} \\
(0.001)\end{array}$ & & & \\
\hline $10-15 \mathrm{~km}$ & & & $\begin{array}{c}-0.022^{* * *} \\
(0.001)\end{array}$ & $\begin{array}{c}-0.029^{* * *} \\
(0.001)\end{array}$ & \\
\hline $15-20 \mathrm{~km}$ & & & $\begin{array}{c}-0.023^{* * *} \\
(0.001)\end{array}$ & $\begin{array}{c}-0.031^{* * *} \\
(0.001)\end{array}$ & \\
\hline linear in $\mathrm{km}$ & & & & & $\begin{array}{c}-0.002^{* * *} \\
(0.000)\end{array}$ \\
\hline Father and child covariates ${ }^{a}$ & Yes & Yes & Yes & Yes & Yes \\
\hline Number of observations & 15,383 & 15,383 & 15,383 & 15,383 & 15,383 \\
\hline Mean of dep. variable & 0.01 & 0.01 & 0.01 & 0.01 & 0.01 \\
\hline F-test of weak instrument & 804.57 & 521.73 & 386.72 & 308.84 & 1207.91 \\
\hline Shea's R-squared & 0.09 & 0.10 & 0.10 & 0.12 & 0.10 \\
\hline
\end{tabular}

Notes: Standard errors clustered on families in parentheses, stars indicate statistical significance: ${ }^{*} p<0.10,{ }^{* *} p<0.05,{ }^{* * *}$ $p<0.01$. ${ }^{a}$ See respective note to Table 6 . 
Table 8: Alternative specifications of the first stage - overclaimed amount in Euro

\begin{tabular}{|c|c|c|c|c|c|}
\hline & $(1)$ & $(2)$ & $(3)$ & (4) & $(5)$ \\
\hline & 2 IV categories & 3 IV categories & 4 IV categories & 5 IV categories & Linear IV \\
\hline \multicolumn{6}{|c|}{ Father's distance-to-bracket between: } \\
\hline $0-2 \mathrm{~km}$ & & & & Base group & \\
\hline $0-5 \mathrm{~km}$ & Base group & Base group & Base group & & \\
\hline $5-20 \mathrm{~km}$ & $\begin{array}{c}-355.630^{* * *} \\
(11.077)\end{array}$ & & & & \\
\hline $2-5 \mathrm{~km}$ & & & & $\begin{array}{c}-266.970^{* * *} \\
(21.165)\end{array}$ & \\
\hline 5-10 km & & $\begin{array}{c}-268.946^{* * *} \\
(12.884)\end{array}$ & $\begin{array}{c}-270.131^{* * *} \\
(12.916)\end{array}$ & $\begin{array}{c}-442.487^{* * *} \\
(19.309)\end{array}$ & \\
\hline $10-20 \mathrm{~km}$ & & $\begin{array}{c}-453.300^{* * *} \\
(12.072)\end{array}$ & & & \\
\hline $10-15 \mathrm{~km}$ & & & $\begin{array}{c}-435.826^{* * *} \\
(14.303)\end{array}$ & $\begin{array}{c}-597.191^{* * *} \\
(19.770)\end{array}$ & \\
\hline $15-20 \mathrm{~km}$ & & & $\begin{array}{c}-464.003^{* * *} \\
(11.820)\end{array}$ & $\begin{array}{c}-628.754^{* * *} \\
(18.164)\end{array}$ & \\
\hline linear in $\mathrm{km}$ & & & & & $\begin{array}{c}-31.500^{* * *} \\
(0.775)\end{array}$ \\
\hline Father and child covariates ${ }^{a}$ & Yes & Yes & Yes & Yes & Yes \\
\hline Number of observations & 15,383 & 15,383 & 15,383 & 15,383 & 15,383 \\
\hline Mean of dep. variable & 183.71 & 183.71 & 183.71 & 183.71 & 183.71 \\
\hline F-test of weak instrument & 1030.67 & 705.10 & 515.39 & 424.22 & 1653.78 \\
\hline Shea's R-squared & 0.12 & 0.13 & 0.13 & 0.16 & 0.13 \\
\hline
\end{tabular}

Notes: Standard errors clustered on families in parentheses, stars indicate statistical significance: ${ }^{*} p<0.10,{ }^{* *} p<0.05,{ }^{* * *}$ $p<0.01$. ${ }^{a}$ See respective note to Table 6 . 
Table 9: Estimation of the intergenerational causal effect in tax evasion behavior

\begin{tabular}{|c|c|c|c|c|c|c|}
\hline & $(1)$ & $(2)$ & $(3)$ & $(4)$ & $(5)$ & (6) \\
\hline & \multicolumn{2}{|c|}{$\begin{array}{l}\text { Cheating } \\
(0 / 1)\end{array}$} & \multicolumn{2}{|c|}{$\begin{array}{c}\text { Overclaimed } \\
\text { amount/income }\end{array}$} & \multicolumn{2}{|c|}{$\begin{array}{l}\text { Overclaimed } \\
\text { Euros }\end{array}$} \\
\hline & OLS & 2SLS & OLS & 2SLS & OLS & 2SLS \\
\hline Father is cheating $(0 / 1)$ & $\begin{array}{l}0.039^{* * *} \\
(0.009)\end{array}$ & $\begin{array}{l}0.047^{* *} \\
(0.022)\end{array}$ & & & & \\
\hline Father's overclaimed amount/income & & & $\begin{array}{l}0.043^{* * *} \\
(0.014) \\
{[0.025]}\end{array}$ & $\begin{array}{l}0.093^{* *} \\
(0.040) \\
{[0.056]}\end{array}$ & & \\
\hline Father's overclaimed amount in Euro & & & & & $\begin{array}{l}0.038^{* * *} \\
(0.010) \\
{[0.033]}\end{array}$ & $\begin{array}{c}0.058^{* *} \\
(0.024) \\
{[0.051]}\end{array}$ \\
\hline \multicolumn{7}{|l|}{ Child characteristics } \\
\hline Distance-to-bracket betw. $5-10 \mathrm{~km}$ & $\begin{array}{l}-0.296^{* * *} \\
(0.010)\end{array}$ & $\begin{array}{l}-0.296^{* * *} \\
(0.010)\end{array}$ & $\begin{array}{l}-0.023^{* * *} \\
(0.001)\end{array}$ & $\begin{array}{l}-0.023^{* * *} \\
(0.001)\end{array}$ & $\begin{array}{l}-328.564^{* * *} \\
\quad(12.199)\end{array}$ & $\begin{array}{c}-328.635^{* * *} \\
\quad(12.150)\end{array}$ \\
\hline Distance-to-bracket above $10-20 \mathrm{~km}$ & $\begin{array}{l}-0.401^{* * *} \\
(0.009)\end{array}$ & $\begin{array}{l}-0.401^{* * *} \\
(0.009)\end{array}$ & $\begin{array}{l}-0.032^{* * *} \\
(0.001)\end{array}$ & $\begin{array}{l}-0.032^{* * *} \\
(0.001)\end{array}$ & $\begin{array}{l}-453.084^{* * *} \\
\quad(10.464)\end{array}$ & $\begin{array}{c}-452.965^{* * *} \\
(10.423)\end{array}$ \\
\hline Female & $\begin{array}{c}0.002 \\
(0.007)\end{array}$ & $\begin{array}{c}0.002 \\
(0.007)\end{array}$ & $\begin{array}{c}-0.001 \\
(0.001)\end{array}$ & $\begin{array}{c}-0.000 \\
(0.001)\end{array}$ & $\begin{array}{c}-4.926 \\
(9.204)\end{array}$ & $\begin{array}{c}-4.743 \\
(9.167)\end{array}$ \\
\hline Log income & $\begin{array}{l}0.056^{* * *} \\
(0.008)\end{array}$ & $\begin{array}{l}0.056^{* * *} \\
(0.008)\end{array}$ & $\begin{array}{c}-0.014^{* * *} \\
(0.002)\end{array}$ & $\begin{array}{c}-0.014^{* * *} \\
(0.002)\end{array}$ & $\begin{array}{l}75.668^{* * *} \\
(10.666)\end{array}$ & $\begin{array}{l}75.376^{* * *} \\
(10.639)\end{array}$ \\
\hline Academic degree & $\begin{array}{c}-0.025 \\
(0.019)\end{array}$ & $\begin{array}{c}-0.025 \\
(0.019)\end{array}$ & $\begin{array}{c}-0.001 \\
(0.002)\end{array}$ & $\begin{array}{c}-0.001 \\
(0.002)\end{array}$ & $\begin{array}{c}-20.427 \\
(24.953)\end{array}$ & $\begin{array}{c}-19.393 \\
(24.833)\end{array}$ \\
\hline White-collar & $\begin{array}{l}0.028^{* * *} \\
(0.007)\end{array}$ & $\begin{array}{l}0.028^{* * *} \\
(0.007)\end{array}$ & $\begin{array}{l}0.002^{* * *} \\
(0.001)\end{array}$ & $\begin{array}{l}0.002^{* * *} \\
(0.001)\end{array}$ & $\begin{array}{l}43.067^{* * *} \\
(9.075)\end{array}$ & $\begin{array}{l}43.033^{* * *} \\
(9.045)\end{array}$ \\
\hline Foreigner & $\begin{array}{c}0.006 \\
(0.009)\end{array}$ & $\begin{array}{c}0.007 \\
(0.009)\end{array}$ & $\begin{array}{c}0.000 \\
(0.001)\end{array}$ & $\begin{array}{c}0.000 \\
(0.001)\end{array}$ & $\begin{array}{c}11.878 \\
(11.446)\end{array}$ & $\begin{array}{c}12.213 \\
(11.412)\end{array}$ \\
\hline Commuting distance in $\mathrm{km}$ & $\begin{array}{l}0.002^{* *} \\
(0.001)\end{array}$ & $\begin{array}{l}0.002^{* *} \\
(0.001)\end{array}$ & $\begin{array}{l}0.000^{* * *} \\
(0.000)\end{array}$ & $\begin{array}{l}0.000^{* * *} \\
(0.000)\end{array}$ & $\begin{array}{c}1.581 \\
(1.144)\end{array}$ & $\begin{array}{c}1.580 \\
(1.140)\end{array}$ \\
\hline Size of ZIP-code area & $\begin{array}{c}-0.000 \\
(0.000)\end{array}$ & $\begin{array}{c}-0.000 \\
(0.000)\end{array}$ & $\begin{array}{c}-0.000 \\
(0.000)\end{array}$ & $\begin{array}{c}-0.000 \\
(0.000)\end{array}$ & $\begin{array}{c}-0.342 \\
(0.284)\end{array}$ & $\begin{array}{c}-0.346 \\
(0.283)\end{array}$ \\
\hline Squared size of ZIP-code area & $\begin{array}{c}-0.000^{*} \\
(0.000)\end{array}$ & $\begin{array}{c}-0.000^{*} \\
(0.000)\end{array}$ & $\begin{array}{c}-0.000 \\
(0.000)\end{array}$ & $\begin{array}{c}-0.000 \\
(0.000)\end{array}$ & $\begin{array}{c}-0.002 \\
(0.002)\end{array}$ & $\begin{array}{c}-0.002 \\
(0.002)\end{array}$ \\
\hline \multicolumn{7}{|l|}{ Father characteristics } \\
\hline Log income & $\begin{array}{c}0.007 \\
(0.010)\end{array}$ & $\begin{array}{c}0.007 \\
(0.010)\end{array}$ & $\begin{array}{c}0.000 \\
(0.001)\end{array}$ & $\begin{array}{c}0.001 \\
(0.001)\end{array}$ & $\begin{array}{l}-4.200 \\
(12.298)\end{array}$ & $\begin{array}{l}-4.801 \\
(12.305)\end{array}$ \\
\hline Academic degree & $\begin{array}{c}-0.002 \\
(0.047)\end{array}$ & $\begin{array}{c}-0.003 \\
(0.047)\end{array}$ & $\begin{array}{c}0.003 \\
(0.005)\end{array}$ & $\begin{array}{c}0.003 \\
(0.005)\end{array}$ & $\begin{array}{l}-2.828 \\
(59.090)\end{array}$ & $\begin{array}{l}-3.348 \\
(58.667)\end{array}$ \\
\hline White-collar & $\begin{array}{c}0.005 \\
(0.008)\end{array}$ & $\begin{array}{c}0.005 \\
(0.008)\end{array}$ & $\begin{array}{c}0.001 \\
(0.001)\end{array}$ & $\begin{array}{c}0.001 \\
(0.001)\end{array}$ & $\begin{array}{c}9.753 \\
(10.052)\end{array}$ & $\begin{array}{c}8.987 \\
(10.011)\end{array}$ \\
\hline Foreigner & $\begin{array}{c}0.003 \\
(0.008)\end{array}$ & $\begin{array}{c}0.003 \\
(0.008)\end{array}$ & $\begin{array}{c}-0.001 \\
(0.001)\end{array}$ & $\begin{array}{c}-0.001 \\
(0.001)\end{array}$ & $\begin{array}{c}6.174 \\
(10.073)\end{array}$ & $\begin{array}{c}6.423 \\
(10.049)\end{array}$ \\
\hline Commuting distance in $\mathrm{km}$ & $\begin{array}{c}-0.001 \\
(0.001)\end{array}$ & $\begin{array}{c}-0.001 \\
(0.001)\end{array}$ & $\begin{array}{c}-0.000 \\
(0.000)\end{array}$ & $\begin{array}{c}-0.000 \\
(0.000)\end{array}$ & $\begin{array}{c}-1.438 \\
(1.601)\end{array}$ & $\begin{array}{c}-1.439 \\
(1.596)\end{array}$ \\
\hline Commuting distance in $\mathrm{km}$ squared & $\begin{array}{c}0.000 \\
(0.000)\end{array}$ & $\begin{array}{c}0.000 \\
(0.000)\end{array}$ & $\begin{array}{c}0.000 \\
(0.000)\end{array}$ & $\begin{array}{c}0.000 \\
(0.000)\end{array}$ & $\begin{array}{c}0.021 \\
(0.026)\end{array}$ & $\begin{array}{c}0.020 \\
(0.026)\end{array}$ \\
\hline Size of ZIP-code area & $\begin{array}{c}-0.000 \\
(0.000)\end{array}$ & $\begin{array}{c}-0.000 \\
(0.000)\end{array}$ & $\begin{array}{c}0.000 \\
(0.000)\end{array}$ & $\begin{array}{c}0.000 \\
(0.000)\end{array}$ & $\begin{array}{c}0.109 \\
(0.309)\end{array}$ & $\begin{array}{c}0.124 \\
(0.308)\end{array}$ \\
\hline Squared size of ZIP-code area & $\begin{array}{r}-0.000 \\
(0.000)\end{array}$ & $\begin{array}{r}-0.000 \\
(0.000)\end{array}$ & $\begin{array}{c}-0.000 \\
(0.000)\end{array}$ & $\begin{array}{c}-0.000 \\
(0.000)\end{array}$ & $\begin{array}{r}-0.001 \\
(0.002)\end{array}$ & $\begin{array}{r}-0.001 \\
(0.002)\end{array}$ \\
\hline Further father and child covariates ${ }^{a}$ & Yes & Yes & Yes & Yes & Yes & Yes \\
\hline Observations & 15,391 & 15,391 & 15,383 & 15,383 & 15,383 & 15,383 \\
\hline Mean of dep. var. & 0.20 & 0.20 & 0.02 & 0.02 & 235.90 & 235.90 \\
\hline S.d. of dep. var & 0.40 & 0.40 & 0.04 & 0.04 & 493.86 & 493.86 \\
\hline R-squared & 0.20 & - & 0.17 & - & 0.17 & - \\
\hline
\end{tabular}

Notes: This table summarizes 2SLS estimation results of the effect of paternal tax evasion behavior on children's tax evasion behavior. Father's distance-to-bracket (i. e., his probability of detection) serves as an IV for the fathers tax evasion decision. Reported estimates are second-stage coefficients with standard errors clustered on families in parentheses below. Values in brackets are beta coefficients. All estimations include child and father birthyear, industry, and regional fixed effects. $*, * *$ and $* * *$ indicate statistical significance at the 10-percent, 5-percent and 1-percent level respectively. ${ }^{a}$ We further control for the following non-tabulated characteristics of father and child: year of birth (binary indicators), sector of employment (17 binary indicators), firm size (binary indicator for employment in a firm with more than 10 employees), and region of residence ( 9 binary indicators). 
Table 10: Placebo-Test using statistically matched father-child pairs

\begin{tabular}{|c|c|c|c|c|c|c|}
\hline & (1) & $(2)$ & $(3)$ & (4) & $(5)$ & (6) \\
\hline & \multicolumn{2}{|c|}{$\begin{array}{l}\text { Cheating } \\
(0 / 1)\end{array}$} & \multicolumn{2}{|c|}{$\begin{array}{l}\text { Overclaimed } \\
\text { amount/income }\end{array}$} & \multicolumn{2}{|c|}{$\begin{array}{l}\text { Overclaimed } \\
\text { Euros }\end{array}$} \\
\hline & OLS & 2SLS & OLS & 2SLS & OLS & 2SLS \\
\hline Father is cheating $(0 / 1)$ & $\begin{array}{c}-0.001 \\
(0.008)\end{array}$ & $\begin{array}{r}-0.013 \\
(0.021)\end{array}$ & & & & \\
\hline Father's overclaimed amount/income & & & $\begin{array}{c}0.002 \\
(0.013)\end{array}$ & $\begin{array}{c}-0.001 \\
(0.038)\end{array}$ & & \\
\hline Father's overclaimed amount in Euro & & & & & $\begin{array}{c}-0.001 \\
(0.009)\end{array}$ & $\begin{array}{r}-0.008 \\
(0.023)\end{array}$ \\
\hline Father and child covariates ${ }^{a}$ & Yes & Yes & Yes & Yes & Yes & Yes \\
\hline Observations & 15,386 & 15,386 & 15,361 & 15,361 & 15,361 & 15,361 \\
\hline R-squared & 0.20 & - & 0.16 & - & 0.17 & - \\
\hline
\end{tabular}

Notes: This table summarizes estimation results equivalent to those presented in Table 9. but based on placebo father-child pairs. These placebo pairs are created by assigning each father to another child that is closest in terms of observable characteristics to his own child. Closeness is defined via nearest neighbor matching, using the following list of observable characteristics: total commuting distance, distance-to-bracket, sex, year of birth, nationality, educational attainment, occupation, earnings, firm size, sector of employment, and zipcode of residence. Standard errors clustered on families in parentheses, stars indicate statistical significance:* $p<0.10,{ }^{* *} p<0.05,{ }^{* * *} p<0.01$. ${ }^{a}$ All models include the same set of covariates as in Table 9. The father's distance-to-bracket (i.e., his probability of detection) serves again as an IV. 
Table 11: Sensitivity analysis of the estimation of the intergenerational causal effect in tax evasion behavior

\begin{tabular}{|c|c|c|c|c|c|c|c|}
\hline & $\begin{array}{c}\quad(1) \\
\text { Alternative } \\
\text { first stage: } \\
4 \text { IV } \text { categories }^{a}\end{array}$ & $\begin{array}{l}\text { (2) } \\
\text { Alternative } \\
\text { first stage: } \\
\text { linear IV }\end{array}$ & $\begin{array}{c}(3) \\
\text { Include very } \\
\text { long commuting } \\
\text { distances }(>60 \mathrm{~km})^{c}\end{array}$ & $\begin{array}{c}(4) \\
\text { Exclude very } \\
\text { short commuting } \\
\text { distances }(<8 \mathrm{~km})^{d}\end{array}$ & $\begin{array}{c}(5) \\
\text { Control for } \\
\text { ZIP-code } \\
\text { distance-to-bracket }^{e}\end{array}$ & $\begin{array}{c}\text { (6) } \\
\text { Control for } \\
\text { ZIP-code } \\
\text { cheating share }\end{array}$ & $\begin{array}{c}(7) \\
\text { Control for } \\
\text { co-worker } \\
\text { cheating share }\end{array}$ \\
\hline \multicolumn{8}{|l|}{ Panel A: Binary cheating variable } \\
\hline $\begin{array}{l}\text { Father is cheating } \\
\text { Distance-to-bracket of ZIP-code } \\
\text { ZIP-code cheater share } \\
\text { Co-worker cheater share }\end{array}$ & $\begin{array}{c}0.047^{* *} \\
(0.022)\end{array}$ & $\begin{array}{l}0.036^{*} \\
(0.022)\end{array}$ & $\begin{array}{l}0.040^{* *} \\
(0.016)\end{array}$ & $\begin{array}{l}0.050^{* *} \\
(0.024)\end{array}$ & $\begin{array}{l}0.047^{* *} \\
(0.023) \\
\text { Yes } \\
\text { No } \\
\text { No }\end{array}$ & $\begin{array}{l}0.044^{* *} \\
(0.022) \\
\text { Yes } \\
\text { Yes } \\
\text { No }\end{array}$ & $\begin{array}{l}0.045^{* *} \\
(0.022) \\
\text { Yes } \\
\text { Yes } \\
\text { Yes }\end{array}$ \\
\hline $\begin{array}{l}\text { Observations } \\
\text { Mean of dep. var. } \\
\text { F-test of weak instrument }\end{array}$ & $\begin{array}{c}15,391 \\
0.20 \\
560.02\end{array}$ & $\begin{array}{c}15,391 \\
0.20 \\
1787.47\end{array}$ & $\begin{array}{c}24,433 \\
0.16 \\
770.52\end{array}$ & $\begin{array}{c}10,726 \\
0.22 \\
687.32\end{array}$ & $\begin{array}{c}15,062 \\
0.20 \\
734.69\end{array}$ & $\begin{array}{c}15,062 \\
0.20 \\
736.40\end{array}$ & $\begin{array}{c}15,062 \\
0.20 \\
737.66\end{array}$ \\
\hline \multicolumn{8}{|l|}{ Panel B: Overclaimed amount/income } \\
\hline Father's overclaimed amount/income ratio & $\begin{array}{c}0.090^{* *} \\
(0.039)\end{array}$ & $\begin{array}{c}0.078^{* *} \\
(0.039)\end{array}$ & $\begin{array}{l}0.061^{*} \\
(0.032)\end{array}$ & $\begin{array}{l}0.088^{* *} \\
(0.042)\end{array}$ & $\begin{array}{c}0.090^{* *} \\
(0.040)\end{array}$ & $\begin{array}{c}0.087^{* *} \\
(0.040)\end{array}$ & $\begin{array}{c}0.089 * * \\
(0.039)\end{array}$ \\
\hline $\begin{array}{l}\text { Distance-to-bracket of ZIP-code } \\
\text { ZIP-code cheater share } \\
\text { Co-worker cheater share }\end{array}$ & & & & & $\begin{array}{l}\text { Yes } \\
\text { No } \\
\text { No }\end{array}$ & $\begin{array}{l}\text { Yes } \\
\text { Yes } \\
\text { No }\end{array}$ & $\begin{array}{l}\text { Yes } \\
\text { Yes } \\
\text { Yes }\end{array}$ \\
\hline $\begin{array}{l}\text { Observations } \\
\text { Mean of dep. var. } \\
\text { F-test of weak instrument }\end{array}$ & $\begin{array}{c}15,383 \\
0.02 \\
386.72\end{array}$ & $\begin{array}{c}15,383 \\
0.02 \\
1207.91\end{array}$ & $\begin{array}{c}24,421 \\
0.01 \\
543.06\end{array}$ & $\begin{array}{c}10,726 \\
0.02 \\
475.13\end{array}$ & $\begin{array}{c}15,054 \\
0.02 \\
510.26\end{array}$ & $\begin{array}{c}15,054 \\
0.02 \\
510.88\end{array}$ & $\begin{array}{l}15,054 \\
0.02 \\
511.75\end{array}$ \\
\hline \multicolumn{8}{|l|}{ Panel C: Absolute overclaimed amount } \\
\hline $\begin{array}{l}\text { Father's overclaimed amount in Euro } \\
\text { Distance-to-bracket of ZIP-code } \\
\text { ZIP-code cheater share } \\
\text { Co-worker cheater share }\end{array}$ & $\begin{array}{c}0.058^{* *} \\
(0.024)\end{array}$ & $\begin{array}{l}0.046^{*} \\
(0.024)\end{array}$ & $\begin{array}{c}0.049^{* * *} \\
(0.018)\end{array}$ & $\begin{array}{l}0.055^{* *} \\
(0.024)\end{array}$ & $\begin{array}{l}0.059^{* *} \\
(0.024) \\
\text { Yes } \\
\text { No } \\
\text { No }\end{array}$ & $\begin{array}{l}0.056^{* *} \\
(0.023) \\
\text { Yes } \\
\text { Yes } \\
\text { No }\end{array}$ & $\begin{array}{l}0.058^{* *} \\
\text { Yes } \\
\text { Yes } \\
\text { Yes }\end{array}$ \\
\hline $\begin{array}{l}\text { Observations } \\
\text { Mean of dep. var. } \\
\text { F-test of weak instrument }\end{array}$ & $\begin{array}{l}15,383 \\
235.90 \\
515.35\end{array}$ & $\begin{array}{c}15,383 \\
235.90 \\
1653.78\end{array}$ & $\begin{array}{l}24,421 \\
183.51 \\
736.09\end{array}$ & $\begin{array}{l}10,726 \\
254.90 \\
642.24\end{array}$ & $\begin{array}{l}15,054 \\
235.90 \\
687.97\end{array}$ & $\begin{array}{l}15,054 \\
234.50 \\
689.04\end{array}$ & $\begin{array}{l}15,054 \\
234.50 \\
690.47\end{array}$ \\
\hline
\end{tabular}

Notes: This table summarizes sensitivity checks of the 2SLS estimation results of the effect of paternal tax evasion behavior on children's tax evasion behavior presented in Table 9. All models include the same set of covariates as in Table 9, and the father's distance-to-bracket (i.e., his probability of detection) serves again as an IV. Across panels different measurements of tax evasion behavior are used. Reported estimates are second-stage coefficients with standard errors clustered on families in parentheses below. ${ }^{*},{ }^{* *}$ and ${ }^{* * *}$ indicate statistical significance at the 10-percent, 5-percent and 1-percent level respectively. ${ }^{a}$ Estimation results are based on an alternative specification of the first stage, which includes in addition a binary indicator for a father's distance-to-bracket between 15-20 km (see column (3) of Table 7). ${ }^{b}$ Estimation results are based on an alternative specification of the first stage, which uses father's linear distance-to-bracket measure as an IV (see column (5) of Table 7). ${ }^{c}$ This estimation sample includes all observations commuting 60 kilometers or more (i. e. those above the highest distance bracket). We include a binary indicator for these commuters as an additional instrument. $d$ This estimation sample excludes all observations with fathers and/or children commuting 8 kilometers or less. $e$ This specification controls for the mean distance-to-bracket in the zip-code of the child's birth cohort. $f$ Additionally includes the mean cheater-share in the zip-code of the child's birth cohort. $g$ Controls for the share of children's co-workers who cheat (see, Paetzold and Winner, 2016). 
Table 12: Siblings: Estimation of the intra-generational causal effect in tax evasion behavior

\begin{tabular}{|c|c|c|c|c|c|c|}
\hline & $(1)$ & $(2)$ & $(3)$ & $(4)$ & $(5)$ & $(6)$ \\
\hline & \multicolumn{2}{|c|}{$\begin{array}{c}\text { Cheating } \\
(0 / 1)\end{array}$} & \multicolumn{2}{|c|}{$\begin{array}{c}\text { Overclaimed } \\
\text { amount/income }\end{array}$} & \multicolumn{2}{|c|}{$\begin{array}{c}\text { Overclaimed } \\
\text { Euros }\end{array}$} \\
\hline & OLS & 2SLS & OLS & 2SLS & OLS & 2SLS \\
\hline Older sibling is cheating $(0 / 1)$ & $\begin{array}{l}0.034^{* * *} \\
(0.010)\end{array}$ & $\begin{array}{c}0.044^{*} \\
(0.023)\end{array}$ & & & & \\
\hline Older sibling's overclaimed amount/income & & & $\begin{array}{l}0.026^{* * *} \\
(0.009)\end{array}$ & $\begin{array}{r}0.045^{*} \\
(0.026)\end{array}$ & & \\
\hline Older sibling's overclaimed amount (EUR) & & & & & $\begin{array}{l}0.034^{* * *} \\
(0.011)\end{array}$ & $\begin{array}{l}0.061^{* *} \\
(0.026)\end{array}$ \\
\hline Siblings' covariates ${ }^{a}$ & Yes & Yes & Yes & Yes & Yes & Yes \\
\hline $\begin{array}{l}\text { Number of observations } \\
\text { F-test of weak instrument }\end{array}$ & 9,650 & $\begin{array}{c}9,650 \\
654.82\end{array}$ & 9,648 & $\begin{array}{c}9,648 \\
429.45\end{array}$ & 9,648 & $\begin{array}{c}9,648 \\
580.51\end{array}$ \\
\hline
\end{tabular}

Notes: This table summarizes 2SLS estimation results of the effect of tax evasion behavior of the older sibling on the younger siblings's tax evasion behavior. The older sibling's distance-to-bracket (i. e., his/her probability of detection) serves as an IV for the older sibling's tax evasion decision. Reported estimates are second-stage coefficients with standard errors clustered on families in parentheses below. Stars indicate statistical significance: ${ }^{*} p<0.10,{ }^{* *} p<0.05,{ }^{* * *} p<0.01$. ${ }^{a}$ We control for the following characteristics of both siblings: year of birth (binary indicators), citizenship (Austrian vs. non-Austrian), sex, educational attainment (academic degree), occupation (blue- vs. white-collar worker), sector of employment (17 binary indicators), firm size (binary indicator for employment in a firm with more than 10 employees), individual earnings, region of residence (9 binary indicators), commuting distance in km (linearly, squared, and with a binary indicator for short commuting distances $<10 \mathrm{~km}$ ), size of ZIP-code area of residence (linear and squared). Further, we control for the older sibling's distance-to-bracket, where we include binary indicators capturing the following intervals: $[0-5) \mathrm{km},[5-10) \mathrm{km}$, and $>10 \mathrm{~km}$. 


\section{Web Appendix}

This Web Appendix (not for publication) provides additional material discussed in the unpublished manuscript 'The Intergenerational Causal Effect of Tax Evasion: Evidence from the Commuter Tax Allowance in Austria' by Wolfgang Frimmel, Martin Halla, and Jörg Paetzold. 


\section{A.1 Misreporting of father cohort (born $<1974)$}

This section replicates Figure 1 of the main text for older cohorts (i.e., commuters born before 1974). As for Figure 1, we pool data across all brackets and display the fraction of over- and underreporters by bins of distance to the workplace. The dashed lines indicate the thresholds, at which the allowance discretely increases to a higher amount. Again, we observe a sharp reaction of taxpayers to these thresholds. The closer commuters live to a respective bracket the more prone they are to misreport their allowance claim. Importantly, the fraction of misreporters falls discontinuously at each bracket threshold, with commuters being much more prone to cheat than to underreport their eligibility. In sum, Figure A.1 shows that taxpayers of older cohorts are also aware of the allowance scheme's structure and its incentive to overreport.

Figure A.1: Distance-to-bracket and misreporting (cohorts $<1974$ )

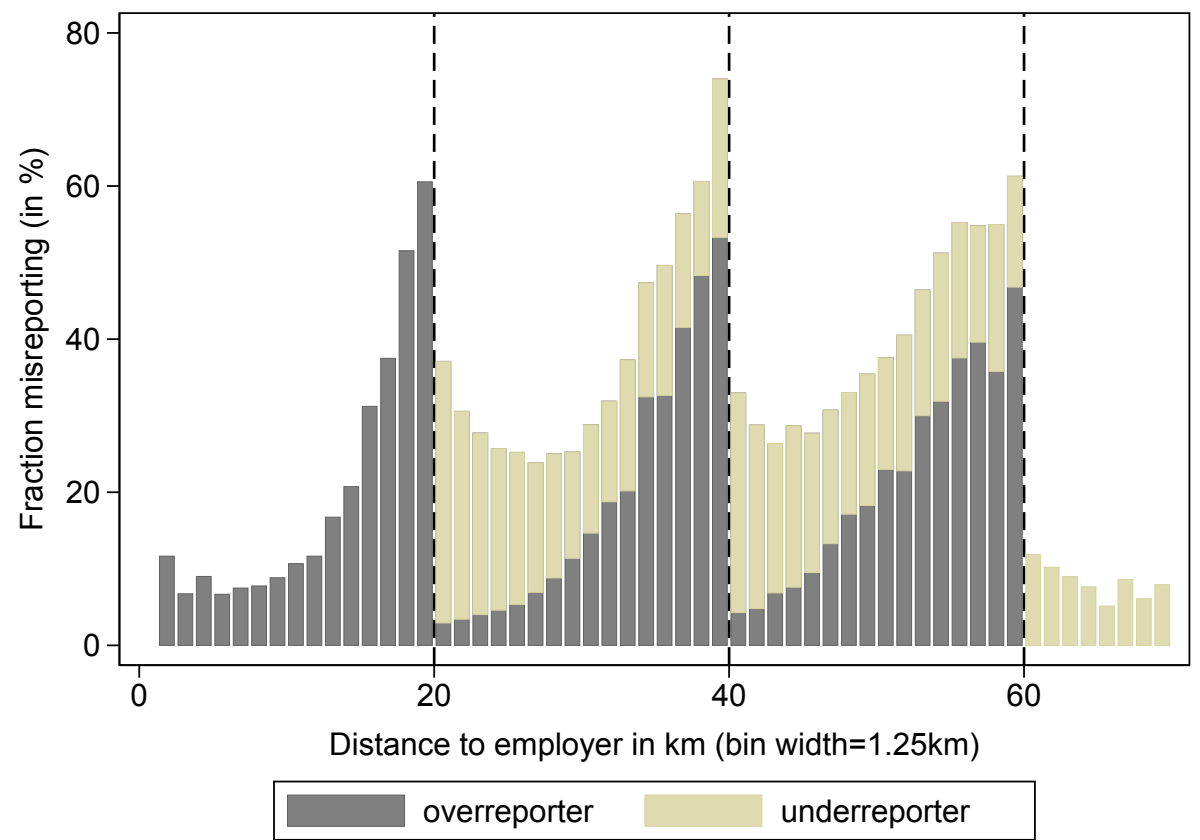

Notes: This figure displays the percent share of misreporters by commuting distance. Each bar is broken down between misreporters who overreport (dark area) and misreporters who underreport (light area). The dashed lines represent the thresholds, where the allowance discontinuously increases to a higher amount (at 20,40, and $60 \mathrm{~km}$, respectively). The histogram includes allowance recipients from cohorts born before 1974 . 


\section{A.2 Take-up of major commuter allowance}

In our main analysis, we have to exclude claimants of the minor commuter allowance scheme (using public transport), because we are not able to measure the actual/true travel distance for these commuters precisely enough. We test therefore, whether we observe a selection of children into the major allowance by father's distance-to-bracket. Figure A.2 plots the fraction of all employed children claiming a major commuter allowance against the distance-to-bracket of their fathers. Specifically, we put all children of the cohort 1974-1994 into $2 \mathrm{~km}$ wide bins of distance-to-bracket of their fathers and plot the fraction of children claiming the major commuter allowance within these bins. We do not find children of fathers close to the bracket threshold to be more likely to claim a major allowance. Thus, we find no evidence that children are systematically selected into the major commuter allowance by their father's distance-to-bracket.

Figure A.2: Children claiming major commuter allowance by father's distance-tobracket

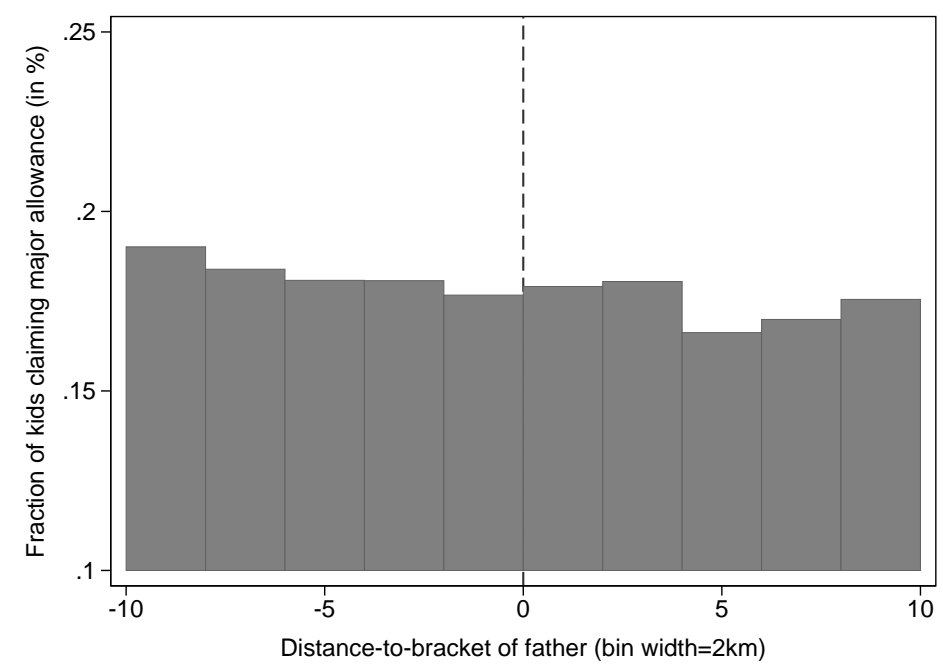

Notes: The figure displays the fraction of all employed children claiming a major commuter allowance against the distance-to-bracket of their fathers. To construct the figure we put all children of the cohort 1974-1994 into $2 \mathrm{~km}$ wide bins of distance-to-bracket of their fathers and plot the fraction of children claiming the major commuter allowance within these bins. The bars show the fraction of claimants for each bin. The dashed line represents the bracket thresholds where the allowance discontinuously increases (i.e., zero represents the 20, 40, and $60 \mathrm{~km}$ threshold, respectively). 


\section{A.3 Test for sorting of fathers around the bracket thresholds}

The Figure A.3 assesses the smoothness of the distribution of fathers' commuting distance around the bracket thresholds using bunching estimations (Saez, 2010). We pool data across all bracket thresholds and put taxpayers in $1 \mathrm{~km}$ wide bins of distance-to-bracket, displaying the number of commuters within such bins. The dashed line represents the bracket thresholds where the allowance discontinuously increases (i.e., zero represents the 20, 40, and $60 \mathrm{~km}$ threshold, respectively). The solid vertical lines indicate the bunching area, i.e. we exclude a window of 2 bins on each side of the thresholds. The solid line beneath the empirical distribution is a seventh-degree polynomial fitted to the empirical distribution excluding the bunching window. The graph is constructed using the fatherchild sample. We do not observe any evidence for fathers' bunching around bracket thresholds (excess mass: coeff. $=-0.0034$, s.e. $=0.256$ ).

Figure A.3: No bunching of fathers around bracket thresholds

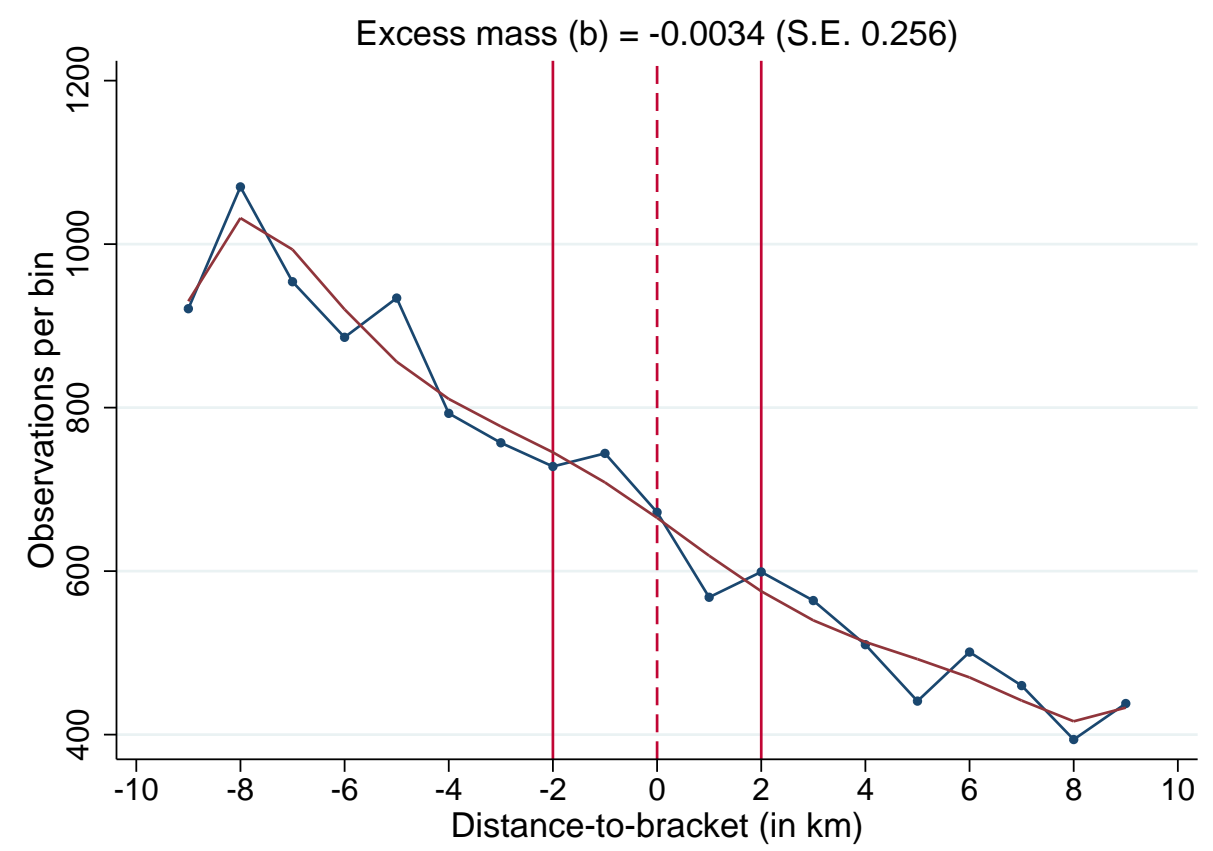




\section{A.4 Determinants of tax morale: evidence from survey data}

In this subsection, we use individual level data from the European and World Values Survey (E/WVS) to study the determinants of self-reported tax morale of Austrian respondents for the years 1990 and 1999. The E/WVS contains information on basic attitudes, beliefs and human values covering religion, morality, politics, work and leisure. In particular, respondents are asked to evaluate on a ten-point scale whether they think 'cheating on tax if [they] have the chance can always be justified, never be justified, or something in between'. We use this questions to construct two alternative measures of tax morale. The first is an ordinal variable, which measures tax morale on the original 10-point scale. The second variable is a binary indicator equal to one, if respondents answered 'never be justified'; and zero otherwise.

For each tax morale variable we summarize in Table A.1 three OLS estimations. In columns (1) and (4), we restrict the estimation to employed individuals (i.e., wage earners) and explain tax morale with sex, income, educational attainment (proxies by school leaving age), occupation, size of place of residence, and age. These specification resemble our estimations of actual tax evasion behavior presented in Table 9. In columns (2) and (5), we control in addition for own children and marital status. In columns (3) and (6), we include all respondents (irrespective of their employment status) and control for their labor market status. 
Table A.1: Determinants of tax morale in Austria using data from the World Values Survey

\begin{tabular}{|c|c|c|c|c|c|c|}
\hline & $(1)$ & $(2)$ & $(3)$ & $(4)$ & $(5)$ & $(6)$ \\
\hline & \multicolumn{3}{|c|}{ Tax morale (ordinal variable) } & \multicolumn{3}{|c|}{ Tax morale (binary indicator) } \\
\hline Female & $\begin{array}{c}0.204^{*} \\
(0.112)\end{array}$ & $\begin{array}{c}0.211^{*} \\
(0.113)\end{array}$ & $\begin{array}{l}0.204^{* * *} \\
(0.075)\end{array}$ & $\begin{array}{c}0.061^{* *} \\
(0.028)\end{array}$ & $\begin{array}{c}0.061^{* *} \\
(0.029)\end{array}$ & $\begin{array}{l}0.065^{* * *} \\
(0.020)\end{array}$ \\
\hline Income (10 point-scale) & $\begin{array}{r}-0.042^{*} \\
(0.024)\end{array}$ & $\begin{array}{c}-0.050^{* *} \\
(0.024)\end{array}$ & $\begin{array}{c}-0.034^{* *} \\
(0.016)\end{array}$ & $\begin{array}{c}-0.012^{* *} \\
(0.006)\end{array}$ & $\begin{array}{c}-0.014^{* *} \\
(0.006)\end{array}$ & $\begin{array}{c}-0.011^{* * *} \\
(0.004)\end{array}$ \\
\hline School leaving age & $\begin{array}{c}-0.073^{* * *} \\
(0.015)\end{array}$ & $\begin{array}{l}-0.070^{* * *} \\
(0.015)\end{array}$ & $\begin{array}{c}-0.051^{* * *} \\
(0.011)\end{array}$ & $\begin{array}{c}-0.022^{* * *} \\
(0.004)\end{array}$ & $\begin{array}{c}-0.021^{* * *} \\
(0.004)\end{array}$ & $\begin{array}{c}-0.015^{* * *} \\
(0.003)\end{array}$ \\
\hline White collar & $\begin{array}{c}0.204 \\
(0.126)\end{array}$ & $\begin{array}{c}0.185 \\
(0.127)\end{array}$ & $\begin{array}{c}0.120 \\
(0.080)\end{array}$ & $\begin{array}{c}0.041 \\
(0.032)\end{array}$ & $\begin{array}{c}0.034 \\
(0.032)\end{array}$ & $\begin{array}{c}0.024 \\
(0.021)\end{array}$ \\
\hline Town size (3 point-scale) & $\begin{array}{c}-0.395^{* * *} \\
(0.083)\end{array}$ & $\begin{array}{c}-0.379^{* * *} \\
(0.084)\end{array}$ & $\begin{array}{c}-0.352^{* * *} \\
(0.056)\end{array}$ & $\begin{array}{c}-0.092^{* * *} \\
(0.021)\end{array}$ & $\begin{array}{c}-0.088^{* * *} \\
(0.021)\end{array}$ & $\begin{array}{c}-0.075^{* * *} \\
(0.015)\end{array}$ \\
\hline Age & $\begin{array}{l}0.016^{* * *} \\
(0.005)\end{array}$ & $\begin{array}{c}0.008 \\
(0.006)\end{array}$ & $\begin{array}{l}0.012^{* * *} \\
(0.003)\end{array}$ & $\begin{array}{l}0.006^{* * *} \\
(0.001)\end{array}$ & $\begin{array}{c}0.003^{*} \\
(0.002)\end{array}$ & $\begin{array}{l}0.003^{* * *} \\
(0.001)\end{array}$ \\
\hline Married & & $\begin{array}{c}0.313^{*} \\
(0.160)\end{array}$ & $\begin{array}{l}0.293^{* * *} \\
(0.091)\end{array}$ & & $\begin{array}{c}0.069^{*} \\
(0.040)\end{array}$ & $\begin{array}{l}0.049^{* *} \\
(0.025)\end{array}$ \\
\hline Children (no/yes) & & $\begin{array}{c}0.052 \\
(0.171)\end{array}$ & $\begin{array}{c}-0.064 \\
(0.109)\end{array}$ & & $\begin{array}{c}0.048 \\
(0.043)\end{array}$ & $\begin{array}{c}0.023 \\
(0.029)\end{array}$ \\
\hline \multicolumn{7}{|c|}{ Labor market status (base group: employed) } \\
\hline Self-employed & & & $\begin{array}{c}-0.304^{* *} \\
(0.150)\end{array}$ & & & $\begin{array}{r}-0.079^{*} \\
(0.040)\end{array}$ \\
\hline Unemployed & & & $\begin{array}{c}0.069 \\
(0.245)\end{array}$ & & & $\begin{array}{c}0.038 \\
(0.066)\end{array}$ \\
\hline Out of labor force & & & $\begin{array}{r}-0.080 \\
(0.100)\end{array}$ & & & $\begin{array}{r}-0.005 \\
(0.027)\end{array}$ \\
\hline Number of observations & 1179 & 1174 & 2500 & 1179 & 1174 & 2500 \\
\hline R-squared & 0.06 & 0.07 & 0.06 & 0.08 & 0.09 & 0.06 \\
\hline Mean of dep. var. & 8.80 & 8.80 & 8.98 & 0.56 & 0.56 & 0.62 \\
\hline S.d. of dep. var. & 1.95 & 1.95 & 1.80 & & & \\
\hline
\end{tabular}

Notes: This table summarizes OLS estimation results of the determinants of tax morale. Tax morale is based on individual responses to the following question from the European and World Values Surveys of the years 1999/2000: 'Please tell me for each of the following statements whether you think it can always be justified, never be justified, or something in between: Cheating on taxes if you have a chance'. Respondents are asked to evaluate this statement on an ordered scale from 'never justifiable' (1) to 'always justifiable' (10). In columns (1) to (3), the dependent variable is an ordinal measurement of tax morale using the original 10-point scale. In columns (4) to (6), the dependent variable is an binary indicator of high tax morale. This variable is equal to one, if respondents answered 'never be justified'; and zero otherwise). Standard errors in parentheses, stars indicate statistical significance: ${ }^{*} p<0.10,{ }^{* *} p<0.05,{ }^{* * *} p<0.01$ 